NASA Téchnical Memorandum 105699

AIAA-92-3087

\title{
CFD Mixing Analysis of Jets Injected From Straight and Slanted Slots Into Confined Crossflow in Rectangular Ducts
}

D.B. Bain and C.E. Smith

CFD Research Corporation

Huntsville, Alabama

and

J.D. Holdeman

Lewis Research Center

Cleveland, Ohio

Prepared for the

28th Joint Propulsion Conference and Exhibit

cosponsored by the AIAA, SAE, ASME, and ASEE

Nashville, Tennessee, July 6-8, 1992

\section{N/S1}




\author{
D. B. Bain and C. E. Smith** \\ CFD Research Corporation \\ 3325-D Triana Blvd. \\ Huntsville, Alabama 35805 \\ J. D. Holdeman ${ }^{\dagger}$ \\ National Aeronautics and Space Administration \\ Lewis Research Center \\ 21000 Brookpark Road \\ Cleveland, Ohio 44135
}

\begin{abstract}
$\underline{\text { Abstract }}$
A CFD study was performed to analyze the mixing potential of opposed rows of staggered jets injected into confined crossflow in a rectangular duct. Three jet configurations were numerically tested: 1) straight $\left(0^{\circ}\right)$ slots, 2) perpendicular slanted $\left(45^{\circ}\right)$ slots angled in opposite directions on top and bottom walls, and 3) parallel slanted $\left(45^{\circ}\right)$ slots angled in the same direction on top and bottom walls. All three configurations were tested at slot spacing-to-duct height ratios $(\mathrm{S} / \mathrm{H})$ of $0.5,0.75$, and $1.0 ;$ a jet-to-mainstream momentum flux ratio $(\mathrm{J})$ of 100 ; and a jet-tomainstream mass flow ratio of 0.383 . Each configuration had its best mixing performance at $\mathrm{S} / \mathrm{H}$ of 0.75 . Asymmetric flow patterns were expected and predicted for all slanted slot configurations. The parallel slanted slot configuration was the best overall configuration at $\mathrm{x} / \mathrm{H}$ of 1.0 for $\mathrm{S} / \mathrm{H}$ of 0.75 .
\end{abstract}

\section{Introduction}

The technology demonstration of low $\mathrm{NO}_{x}$ combustors applicable to commercial aircraft is a subject of ongoing research ${ }^{1}$. One combustor concept currently being evaluated experimentally is the Rich-burn/Quick-mix/Lean-burn (RQL) combustor, originally conceived and developed for industrial combustors ${ }^{2,3}$. A key design technology required for successful demonstration of the RQL is a method of rapidly mixing bypass air with rich-burn gases. To identify improved mixing schemes, a number of recent studies have been performed ${ }^{4,}, 6,7$. The current investigation is focused on jet mixing in rectangular cross-sectional geometries in order to identify orifice configurations with the most potential for annular combustors.

In past studies (see Holdeman ${ }^{8}$ ) applicable to conventional gas turbine dilution zones, it was shown that the rate of mixing and penetration of a row of jets in crossflow is governed mainly by the jet-to-mainstream momentum flux ratio (J) and hole spacing-to-duct height ratio $(\mathrm{S} / \mathrm{H})$. One-sided injection (from one wall only) and twosided injection (from top and bottom walls) were studied. Optimum mixing configurations were identified as shown in Table $1^{8}$. Of the configurations studied, two-sided, opposed (in

$\begin{array}{ll}* & \text { Project Engineer } \\ \text { ** } & \text { Member, AIAA } \\ & \text { Manager, Application Projects } \\ +\quad & \text { Member AIAA } \\ & \text { Senior Research Engineer } \\ & \text { Senior Member, AIAA }\end{array}$

Copyright $\odot 1992$ by the American Institute of Aeronautics and Astronautics, Inc. No copyright is asserted in the United States under Title 17, U.S. Code. The U.S. Government has a royalty-free license to exercise all rights under the copyright claimed herein for Governmental purposes. All other rights are reserved by the copyright owner. 
the same axial plane), staggered (alternate between top and bottom walls in lateral direction) holes were suggested to be the best mixing configuration if the jets penetrated past each other. However, this conclusion was based on relatively few two-sided experimenial tests, and it is still unclear if opposed, staggered holes are really better than opposed, inline holes.

In can geometries, air injection through $45^{\circ}$ slanted slots is thought to enhance mixing by introducing swirl into the mixing zone that enhances lateral spreading, albeit at a reduction in jet penetration. It was shown by Novick and Troth $^{9}$ that slanted slots were better mixers than holes and straight slots for a select few configurations. However, a systematic study, either experimentally or numerically, has not been performed to show that the slanted slot configuration is a better mixing configuration than the straight slot configuration.

This investigation examined the mixing effectiveness of opposed, staggered jets injected through straight $\left(0^{\circ}\right)$ slots and slanted $\left(45^{\circ}\right)$ slots into a rectangular crossflow. Three different configurations were studied:

1. straight slots as a baseline;

2. perpendicular slanted $\left(45^{\circ}\right)$ slots (angled in opposite directions on top and bottom walls); and

3. parallel slanted $\left(45^{\circ}\right)$ slots (angled in the same direction on top and bottom walls).

Note that the orifice centerlines were staggered between top and bottom walls for all configurations studied. Also, note that there are no counterpart configurations in cylindrical geometries.

\section{CFD Code}

The approach in this study was to perform 3-D numerical calculations on a generic geometry section. A CFD code named REFLEQS ${ }^{10,11}$ was used to perform the computations. The basic capabilities/methodologies in REFLEQS include:

1. Solution of two- and three-dimensional
Navier-Stokes equations for incompressible and compressible flows;

2. Cartesian, polar, and non-orthogonal body-fitted coordinates;

3. Porosity-resistivity techniques for flows with internal blockages;

4. Fully implicit and strongly conservative formulation;

5. Three differencing schemes: upwind, hybrid, and central differencing with damping terms;

6. Standard, extended, and low Reynolds number $k-\varepsilon$ turbulence models, and the multiple-scale turbulence model of Chen;

7. Instantaneous, one-step and two-step combustion models;

8. Modified form of Stone's strongly implicit solver; and

9. Pressure-based solution algorithms including SIMPLE and a variant of SIMPLEC.

\section{Validation Case for Slanted Slot Jet Mixing}

One slanted slot validation case was selected from the Dilution Jet Mixing Program 8,12 . The selected case consisted of jets injected through single-sided $45^{\circ}$ slanted slots into a rectangular crossflow. The geometry and flow conditions are described in Figure 1.

\section{Grid}

The numerical computations were performed with the grid shown in Figure 2. Only one slot was modeled to conserve computational time. The grid consisted of 47,488 cells, 53 in the axial (x) direction, 28 in the vertical (y) direction, and 32 in the lateral $(\mathrm{z})$ direction. The origin of the coordinate system in the axial direction is located at the slot center. The slot had an aspect ratio of 2.6 and was modelled using 128 cells. In the axial direction, the calculation domain began one duct height upstream (4 inches, $0.1016 \mathrm{~m}$ ) and extended 3 duct heights downstream (12 inches, $0.3048 \mathrm{~m}$ ) of the slot's leading edge.

\section{Numerics}

The following conservation equations were solved: u momentum, $\mathrm{v}$ momentum, $\mathrm{w}$ momentum, 
mass (pressure correction), total enthalpy (h), turbulent kinetic energy (k), and turbulent energy dissipation $(\varepsilon)$. The convective fluxes were calculated using upwind differencing, and the diffusive fluxes were calculated using central differencing. The standard $k-\varepsilon$ turbulence model was employed and conventional wall functions were used. Thermal properties (specific heat and laminar viscosity) of air were calculated as a function of temperature. A turbulent Prandtl number of 0.9 was assumed. A uniform velocity profile was assumed for both mainstream and jet flows. The inlet turbulence levels were determined by analyzing the flow from upstream screens to the test section. The inlet mainstream and jet turbulence levels were:

$$
\begin{array}{cl}
\text { MAINSTREAM } & \text { JET } \\
\text { u } / \mathrm{U}=0.20 \quad \mathrm{~V} / \mathrm{V}=0.20 \\
\ell_{\mathrm{t}}=0.05 \mathrm{H} \quad \ell_{\mathrm{t}}=0.05 \mathrm{D} \\
\text { where } \quad \mathrm{u}=\text { rms of } \mathrm{U} \text { velocity fluctuation } \\
\mathrm{V}=\text { rms of } \mathrm{V} \text { velocity fluctuation } \\
\mathrm{U}=\text { averaged velocity in } \mathrm{X} \text { direction } \\
\mathrm{V}=\text { averaged velocity in } \mathrm{Y} \text { direction } \\
\mathrm{H}=\text { duct height } \\
\mathrm{D}=\text { equivalent hole diameter } \\
\ell_{\mathrm{t}}=\text { turbulent length scale. }
\end{array}
$$

The top and bottom walls were treated as no-slip boundaries and the lateral boundaries were treated as cyclic (meaning properties leaving a cell on one boundary enter the corresponding cell on the other boundary). A fixed pressure exit boundary was specified.

\section{Convergence}

All error residuals were reduced at least 5 orders of magnitude, and continuity was conserved in each axial plane to the fifth decimal. Convergence was relatively smooth requiring about 450 iterations. A converged solution required approximately $0.75 \mathrm{CPU}$ hours on a CRAY-YMP computer.

\section{$\underline{\text { Results }}$}

The flow vectors at $\mathrm{x} / \mathrm{H}=0.0,0.5,1.0$, and 2.0 are shown in Figure 3. It can be seen that the mainstream flow is forced to the upper wall. As the mainstream flow passes by the jet, the jet acts like a stator vane, forcing the mainstream flow to turn. The turning of the mainstream puts an equal, but opposite, turning force on the jet. Thus, at $\mathrm{x} / \mathrm{H}$ of 2.0 , the mainstream flow is moving from right to left on the top wall, while the jet flow is moving from left to right on the bottom wall. A slip line separates the two flows.

Temperature isotherms for the numerical analysis and experimental measurements are shown in Figure 4. The results are shown for two axial (yz) planes, $\mathrm{x} / \mathrm{H}=0.25$ and $\mathrm{x} / \mathrm{H}=0.50$. Overall, good agreement is seen. The jet penetration coincides well with the experimental data. As is commonly seen with CFD codes, the downstream mixing is underpredicted, although not as severely underpredicted as shown in Reference 8. Also, the numerical results show a lag in the lateral shift of the vortex as the flow moves downstream. Overall, in an engineering sense, it was shown that the CFD code could model the slanted slot quite well, thus providing the framework for numerical experiments to be explained in the sections that follow.

\section{Numerical Test Configuration and Flow Conditions}

A schematic of the test configuration is shown in Figure 5. The height of the mixing section was 4 inches $(0.1016 \mathrm{~m})$, and the width was 12 inches $(0.3048 \mathrm{~m})$. The mainstream flow entered the calculation domain one duct height upstream $(\mathrm{x} / \mathrm{H}=-1.0)$ of the slots and continued downstream, making the total axial length 28 inches $(0.7112 \mathrm{~m})$. The model consisted of top and bottom wall jet injection into a cold mainstream flow.

Ten different slot configurations were analyzed as shown in Figure 6 and Table 2. As $\mathrm{S} / \mathrm{H}$ was varied from 0.5 to 1.0 , the slot dimensions changed to maintain constant jet-to-mainstream mass flow ratio. The slots were straight (long dimension in direction of mainstream) or slanted $45^{\circ}$ to the mainstream flow direction. Note the rows on the top and bottom walls are in the same axial plane, but that the orifices are staggered in the lateral direction. For slanted slots, the slots 
were either parallel to each other on top and bottom walls, or perpendicular to each other on top and bottom walls.

The flow conditions of the mainstream and jets were:

$$
\begin{aligned}
& \text { MAINSTREAM JETS } \\
& \begin{array}{lll}
\mathrm{U}_{\infty}=5 \mathrm{~m} / \mathrm{s} & \mathrm{V}_{\mathrm{j}}=50 \mathrm{~m} / \mathrm{s} \\
\mathrm{T}_{\infty}=300^{\circ} \mathrm{K} & \mathrm{T}_{\mathrm{j}}=300^{\circ} \mathrm{K} \\
\mathrm{u} / \mathrm{U}_{\infty}=0.20 & \mathrm{v} / \mathrm{V}_{\mathrm{j}}=0.20 \\
\boldsymbol{\ell}_{\mathrm{t}}=0.2 \mathrm{H} & \boldsymbol{\ell}_{\mathrm{t}}=0.2 \mathrm{D}
\end{array} \\
& \begin{aligned}
\mathrm{P} & =1 \times 10^{5} \mathrm{~Pa} \\
\mathrm{~J} & =100 \\
\mathrm{~m}_{\mathrm{j}} / \mathrm{m}_{\infty} & =0.383
\end{aligned}
\end{aligned}
$$

where $\infty=$ mainstream flow conditions

$\mathrm{j}=$ jet conditions

$\mathrm{D}=$ equivalent hole diameter.

The turbulent length scales for the mainstream and jets were varied between five and twenty percent of their characteristic dimensions without any appreciable difference in the calculations.

\section{Details of Numerical Calculations}

\section{Grid}

The grid used for the numerical mixing model is presented in Figure 7 . The grid consisted of 145,600 cells, 65 cells in the axial (x) direction, 28 cells in the vertical (y) direction, and 80 cells in the lateral $(z)$ direction. The slot had an aspect ratio of four-to-one and was composed of 144 ( $24 \mathrm{x}$ 6) cells. In the axial direction, the grid distribution in the slot region was uniform. The grid upstream and downstream of the slot region was expanded/contracted so that the cell adjacent to the slot region matched the cell size in the slot region. The cells in the vertical direction were all of uniform size. In the lateral direction, six zones were used, and the grid distribution in the slot regions was uniform.

Note that the lateral boundaries are located at the midplanes between jet centerlines. Most of the analyses presented in this paper were performed using this lateral arrangement.
However, in some cases to be discussed later, two other lateral arrangements were used. First, geometrically symmetric configurations (straight slots) were run with the lateral domain between the jet centerline on the top wall and the jet centerline on the bottom wall. Second, in some checkcases, the lateral boundaries were placed between jet centerlines on the same wall.

\section{$\underline{\text { Numerics }}$}

The same numerics and models were employed as discussed in the validation case.

\section{Convergence}

Similar convergence criteria was used as in the validation case. Due to the significant increase in grid size, the required CRAY-YMP computer time per case increased to approximately $4 \mathrm{CPU}$ hours.

\section{Data Postprocessing}

To quantify mixing effectiveness, the areaaveraged standard deviation of jet flow was calculated in each axial plane. The areaaveraged standard deviation $(\sigma)$ of jet flow is defined as

$$
\sigma=\sqrt{\frac{1}{A_{\text {TOT }}} \sum_{i} A_{i}\left(f_{i}-f_{\text {avg }}\right)^{2}}
$$

where

$$
\begin{aligned}
& \mathrm{A}_{\mathrm{TOT}}=\text { total flow area in each axial plane } \\
& \mathrm{A}_{\mathrm{i}}=\text { flow area of cell } i \\
& \mathrm{f}_{\mathrm{i}}=\text { jet mass fraction in cell } i \\
& \mathrm{f}_{\mathrm{avg}}=\theta_{\mathrm{EB}}^{8}=\frac{\dot{\mathrm{m}}_{\mathrm{j}}}{\dot{\mathrm{m}}_{\mathrm{l}}+\mathrm{m}_{\infty}}
\end{aligned}
$$

The area-averaged standard deviation of jet flow was selected as the parameter of interest in order to compare numerical results with experimental results. Mass-averaged standard deviations were also calculated in this study, and they gave essentially the same results as the area-averaged numbers. For the sake of clarity, 
only area-averaged standard deviations are reported in this paper.

Unmixedness ${ }^{6}$ is defined as $\sigma / \mathrm{f}_{\text {avg }}$. Relative unmixedness ${ }^{6}$ (which bounds unmixedness between 0 and 1 ) is defined as:

$$
\chi=\frac{\sigma / f_{\text {avg }}}{F}
$$

where

$$
F=\sqrt{\frac{1-f_{a v g}}{f_{a v g}}}=\left(\frac{\dot{m}_{j}}{\dot{m}_{\infty}}\right)^{-1 / 2}
$$

For this study, $\mathrm{F}$ is 1.62.

\section{7. $\underline{\text { Results }}$}

\section{Straight Slots}

For straight slots, two different sets of solutions were obtained. In the first set of solutions, lateral symmetry boundaries were imposed to account for the slot geometry being symmetric. The lateral domain went from jet centerline on the top wall to jet centerline on the bottom wall, and symmetry conditions were imposed on the lateral (xy) boundaries. The second set of solutions for straight slots was obtained by analyzing one full cyclic pattern, going from midplane to midplane between slots (in the lateral direction) and including one slot on the top wall and one slot on the bottom wall. Cyclic boundary conditions were assumed on the lateral (xy) boundaries. With this assumption, the flow is permitted to exit and enter the lateral boundaries. This simulates an annular combustor with walls having infinite radius of curvature.

Solutions with Symmetric Lateral Boundaries: The numerical results for the lateral symmetric boundary cases are shown in Figure 8. Figure 8 presents jet mass fraction color concentration maps for three $\mathrm{S} / \mathrm{H}$ ratios $(0.5,0.75$, and 1.0$)$ and four $\mathrm{x} / \mathrm{H}$ ratios $(0.0,0.25,0.50$ and 1.0$)$. The origin of the axial $(x / H)$ planes was located at the center of the slots. In terms of $\mathrm{NO}_{x}$ production, it is more appropriate to represent the downstream distances as a function of the orifices' leading edge. An alternate coordinate system in terms of $x^{\prime}$ was established that had its origin at the orifice leading edge. Both $\mathrm{x} / \mathrm{H}$ and $\mathrm{x}^{\prime} / \mathrm{H}$ distances are shown in the figure. The jet mass fraction color bar has an arrow signifying the overall jet mass fraction at equilibrium (0.277).

The multiple cycles shown in Figure 8 were generated graphically. For each $\mathrm{S} / \mathrm{H}$ case, the same cross-sectional flow area is shown, encompassing twelve jets for $\mathrm{S} / \mathrm{H}$ of 0.5 , eight jets for $\mathrm{S} / \mathrm{H}$ of 0.75 , and six jets for $\mathrm{S} / \mathrm{H}$ of 1.0 .

For $\mathrm{S} / \mathrm{H}$ of 0.5 , the jets do not fully penetrate to the opposite wall. The mainstream flow is forced to the walls, and the jet flow occupies the center of the duct. For $\mathrm{S} / \mathrm{H}$ of 0.75 and 1.0, the jets penetrate to the opposite wall, as evidenced by backflow on the walls (see $x / H=0.0$ ). For $S / H$ of 1.0 , the mainstream flow passes between jets in the center of the duct.

A qualitative comparison of mixing effectiveness can be made by close examination of Figure 8. By comparing the color patterns at $x / H$ of $0.25,0.50$, and 1.0 , it can be seen that the best mixing occurs at $\mathrm{S} / \mathrm{H}=0.75$. A more quantitative comparison of mixing is presented in Figure 12, where relative unmixedness is plotted as a function of $x / H$. The configurations with $\mathrm{S} / \mathrm{H}$ of 0.5 and 0.75 are clearly superior to $\mathrm{S} / \mathrm{H}$ of 1.0 . While both configurations have nearly identical unmixedness values $(\approx 0.042)$ at $\mathrm{x} / \mathrm{H}$ of 1.0 , it can be seen that $\mathrm{S} / \mathrm{H}$ of 0.75 is mixed better at all $\mathrm{x} / \mathrm{H}$ upstream of 1.0. It is hypothesized that the integrated area under the unmixedness curve is probably a good indicator of overall mixing effectiveness, hence $\mathrm{S} / \mathrm{H}$ of 0.75 is probably better in terms of reducing $\mathrm{NO}_{x}$ emissions. Further reacting CFD analysis will have to be performed to verify this hypothesis.

Solutions with Cyclic Lateral Boundaries: Figure 9 displays the results for the cyclic cases. For $\mathrm{S} / \mathrm{H}$ of 0.5 , the flowfield is symmetric about the lateral planes through the jet centerlines, having a flow pattern identical to the symmetric boundary case discussed previously. However, for $\mathrm{S} / \mathrm{H}$ of 0.75 and 1.0, the flowfield is quite different from the symmetric boundary cases. The 
flow asymmetry causes the jets to pair-up, allowing little opening for the mainstream to pass through the paired jets, but more opening for the mainstream to pass between jet pairs. It is interesting to note that for $\mathrm{S} / \mathrm{H}$ of 0.75 the flow flipped in one direction, while for $\mathrm{S} / \mathrm{H}$ of 1.0 , the flow flipped in the opposite direction. Thus, it appears either flipped solution is attainable and stable.

Qualitatively, it appears from Figure 9 that the best mixing occurs for $\mathrm{S} / \mathrm{H}$ of 0.75 . Figure 13 presents the unmixedness results for the cyclic boundary cases. As with the symmetric boundary cases, the best mixing occurs for $\mathrm{S} / \mathrm{H}$ of 0.75 for the cyclic cases.

In rectangular rig tests, flow symmetry has always been measured. It is hypothesized that sidewalls force the symmetric flow patterns by suppressing flow in the lateral direction at the walls. In annular combustors, the flowfield may resemble the flow solutions attained with cyclic boundaries. Future numerical tests modelling multiple jets with and without sidewalls will be executed to verify this hypothesis.

Check Cases: In hindsight, to eliminate any effects caused by other factors, a common lateral domain should have been used for both sets of solutions. The lateral domain should have extended from jet centerline to jet centerline on one wall, and symmetric and cyclic lateral boundaries should have been imposed on the same grid. To check the computed flow results in Figures 8 and 9 , two repeat cases $(\mathrm{S} / \mathrm{H}$ of 0.75 ) were performed with the lateral arrangement from jet centerline-to-jet centerline on the top wall. In one case, symmetric lateral boundaries were imposed, and for the other case, cyclic lateral boundaries were imposed. The computed flow patterns were exactly the same as the computed results in Figures 8 and 9. Thus, the results presented in this paper are consistent with the imposed lateral boundary conditions.

\section{Perpendicular Slanted Slots}

For the perpendicular slanted slots, the geometry is asymmetric, and hence this configuration must be modelled using cyclic lateral boundary conditions. The jet mass fraction concentration maps for perpendicular slanted slots are presented in Figure 10. The jets from perpendicular slanted slots penetrate less than those from straight slots. The jets penetrate to the opposite walls only for $\mathrm{S} / \mathrm{H}$ of 1.0 , and only a small amount of backflow is evident for $\mathrm{S} / \mathrm{H}$ of 1.0. The jets pair up as would be expected based on the geometry. For the perpendicular slanted slots, the flow is asymmetric for all $\mathrm{S} / \mathrm{H}$, including $\mathrm{S} / \mathrm{H}$ of 0.5 . Physically, the asymmetry is caused by the induced swirl of the mainstream flow as it passes the angled jets (see earlier validation case).

For $\mathrm{S} / \mathrm{H}$ of 0.5 , the jets do not penetrate past each other. Thus, the jet flow is concentrated in the center of the duct, and the mainstream flow is concentrated on the walls. For $\mathrm{S} / \mathrm{H}$ of 0.75 , the mainstream flow passes between the paired jets and appears to be the most mixed at the displayed axial locations. For $\mathrm{S} / \mathrm{H}$ of 1.0 , it is obvious that the gap between paired jets is too large, and needs to be reduced to improve mixedness.

Whereas the jet pairing appears to be arbitrary for straight slots (depending on which way the flow flipped), the jet pairing is defined by the geometric configuration for perpendicular slanted slots. The slots' midpoints are uniformly spaced, making the leading edges of the slots unevenly spaced (see Figure 6). Hence, the jets will pair-up according to which slots have their leading edges closest together. To eliminate the jet pairing and, hopefully, improve jet mixing, the slot spacing can be modified.

An alternate slot spacing with $\mathrm{S} / \mathrm{H}$ of 1.0 was analyzed to show the feasibility of improving jet mixing for perpendicular slanted slots (see Figure 6 for spacing). For the alternate spacing, the slots' leading edges were equally spaced. The results are shown in Figure 11. It can be seen that the alternate slot spacing forces the bottom jets to penetrate about halfway between the top jets. The even lateral distribution of the jets' leading edges better distributes the mainstream flow between jets. 
Comparison of unmixedness results for the perpendicular slanted slots is shown in Figure 14 for the $\mathrm{S} / \mathrm{H}$ parametrics. It can be seen that the best spacing is S/H of 0.75 . Figure 15 shows the effect of the alternate slot spacing to eliminate jet pairing. It can be seen that a more uniform lateral distribution of the jets' leading edges does, indeed, improve jet mixing for $\mathrm{S} / \mathrm{H}$ of 1.0 .

\section{Parallel Slanted Slots}

Figure 16 shows the jet mass fraction concentrations for the parallel slanted slot configuration. Except for S/H of 1.0, the parallel slanted slots penetrated less than the straight slots. For $\mathrm{S} / \mathrm{H}$ of 1.0 , the jets originating from the bottom wall penetrate to the opposite wall and exhibit significant backflow, almost identical to the straight slot cases at S/H of 1.0. However, the jets originating from the top wall penetrate significantly less than the bottom wall jets, and significantly less than the straight slot cases.

Flow asymmetry was predicted in this case also. However, in contrast to the previous cases, the parallel slanted slots produced a flowfield on the top wall completely different than the flowfield on the bottom wall. The cause of the phenomena is still being investigated. It should be noted that the flowfield flipped one way for $\mathrm{S} / \mathrm{H}$ of 0.75 , and the other way for $\mathrm{S} / \mathrm{H}$ of 1.0 . By starting with the restart file from the converged solution for $\mathrm{S} / \mathrm{H}$ of 1.0 , a different (i.e., opposite direction) flipped solution could be obtained for $\mathrm{S} / \mathrm{H}$ of 0.75 . Thus, as was shown with straight slots, either flipped solution is attainable and stable.

For $\mathrm{S} / \mathrm{H}$ of 0.5 , the parallel slanted slot jets only penetrate to mid-duct, thus forcing the mainstream flow to the walls and resulting in poor mixing. For $\mathrm{S} / \mathrm{H}$ of 0.75 , the jets penetrate slightly past each other, and appear to mix out quite well. For $\mathrm{S} / \mathrm{H}$ of 1.0 , the bottom jets overpenetrate, and jet pairing produces a large gap for mainstream flow to pass through. Figure 17 shows the unmixedness levels for each spacing. The effect of $\mathrm{S} / \mathrm{H}$ is much more pronounced for parallel slanted slots compared to perpendicular slanted slots. $\mathrm{S} / \mathrm{H}$ of 0.75 is the best spacing for this configuration, the same as for straight slots and perpendicular slots.

A comparison between all configurations is presented in Figure 18 for $\mathrm{S} / \mathrm{H}$ of 0.75 . At $\times / \mathrm{H}$ of 1.0 , the best mixed configuration is the parallel slanted slot configuration, followed in order by straight slots (symmetric lateral boundaries), straight slots (cyclic lateral boundaries), and perpendicular slanted slots. If overall mixedness (lowest $\mathrm{NO}_{\mathrm{x}}$ ) is based on the integrated area under the unmixedness curves, the parallel slanted slots and straight slots (symmetric lateral boundaries) are nearly equal, and the straight slots (cyclic lateral boundaries) and perpendicular slanted slots are much inferior. It should be mentioned that alternate spacings for perpendicular slanted slots to more uniformly distribute the jets laterally should improve its mixing performance, but it is unlikely to improve its performance better than the parallel slanted slots.

\section{Conclusions}

A CFD parametric study was performed on opposed rows of staggered jets mixing in a confined rectangular crossflow. Three configurations were analyzed: 1) straight $\left(0^{\circ}\right)$ slots, 2) perpendicular slanted $\left(45^{\circ}\right)$ slots, and 3 ) parallel slanted $\left(45^{\circ}\right)$ slots. For a jet-tomainstream momentum flux ratio (J) of 100 , all three configurations produced their best mixing at a slot spacing-to-duct ratio $(\mathrm{S} / \mathrm{H})$ of 0.75 (compared to $\mathrm{S} / \mathrm{H}$ of 0.5 and 1.0 ). The parallel slanted slots produced the best overall mixing at $\mathrm{x} / \mathrm{H}$ of 1.0 , having an unmixedness value of 0.037 , compared to 0.050 for perpendicular slanted slots, 0.047 for cyclic boundary straight slots, and 0.042 for symmetric boundary straight slots. Asymmetric flow patterns were predicted for most configurations when cyclic lateral boundaries were assumed. Such flow patterns are expected to occur in annular combustors, but rectangular rigs with sidewalls may force symmetric flow patterns and/or contaminate the mid-duct measurements. Future study of the ramifications of asymmetric/symmetric flow patterns in rectangular geometries is warranted. 


\section{Acknowledgements}

The authors wish to thank NASA Lewis Research Center for funding this work under NASA Contract NAS3-25967, and for the use of NAS Computer time. Valuable discussions and assistance were provided by Mr. Milind Talpallikar, Dr. Vincent Harrand, and Dr. Scott Crocker of CFD Research Corporation. Our thanks also are extended to Ms. Kathy W. Rhoades for preparing this typescript.

\section{0. $\underline{\text { References }}$}

1. R. J. Shaw, "Engine Technology Challenges for a 21st Century High Speed Civil Transport," AIAA Tenth International Symposium on Air Breathing Engines, September 1-6, 1991 (Also NASA TM 104363).

2. S. A. Mosier and R. M. Pierce, "Advanced Combustion Systems for Stationary Gas Turbine Engines," Vol. I, EPA Contract 68-022136, 1980.

3. R. M. Pierce, C. E. Smith, and B. S. Hinton, "Advanced Combustion Systems for Stationary Gas Turbine Engines," Vol. III, EPA Contract 68-02-2136, 1980.

4. M. V. Talpallikar, C. E. Smith, M. C. Lai, and J. D. Holdeman, "CFD Analysis of Jet Mixing in Low $\mathrm{NO}_{x}$ Flametube Combustors," ASME Paper 91-GT-217, to be published in ASME Transactions, Journal of Engineering for Gas Turbines and Power, 1992 (Also NASA TM 104466).

5. C. E. Smith, M. V. Talpallikar, and J. D. Holdeman, "A CFD Study of Jet Mixing in Reduced Flow Areas for Lower Combustor Emissions," AIAA Paper 91-2460, June, 1991, (Also NASA TM 104411) .

6. A. Vranos, D. S. Liscinsky, B. True, and J. D. Holdeman, "Experimental Study of CrossStream Mixing in a Cylindrical Duct," AIAA Paper 91-2459, June, 1991 (Also NASA TM 105180).

7. M. S. Hatch, W. A. Sowa, G. S. Samuelsen, and J.D. Holdeman, "Jet Mixing Into a Heated Cross Flow in a Cylindrical Duct: Influence of Geometry and Flow Variations," AIAA Paper 92-0773, January, 1992 (Also NASA TM 105390).
8. J. D. Holdeman, "Mixing of Multiple Jets with a Confined Subsonic Crossflow," AIAA Paper AIAA-91-2458, 1991 (Also NASA TM 104412).

9. A. S. Novick and D. L. Troth, "Low $\mathrm{NO}_{x}$ Heavy Fuel Combustor Concept," NASA CR165367, 1981.

10. A. J. Przekwas, et al., "REFLEQS-3D: A Computer Program for Turbulent Flows With and Without Chemical Reaction, Volume 1: User's Manual," CFDRC Report GR-89-4, January 1990.

11. C. E. Smith, M. L. Ratcliff, A. J. Przekwas, S. D. Habchi, and A. K. Singhal, "Modeling of Turbulent Combustion in Liquid Rocket Engine Components," NASA MSFC Contract NAS8-37619, SBIR Phase I Final Report, CFDRC Report 4045/1, 1988.

12. R. Srinivasan, G. Myers, E. Coleman, and C. White, "Dilution Jet Mixing Program," Phase III Report, NASA CR-174884, September 1985.

Table 1. Spacing and Momentum-Flux Ratio Relationships

\begin{tabular}{|l|c|}
\hline \multicolumn{1}{|c|}{ Configuration } & $\mathrm{C}=(\mathrm{S} / \mathrm{H}) \sqrt{(\mathrm{J})}$ \\
\hline Single-side injection: & $<1.25$ \\
Under-penetration & 2.5 \\
Optimum & $>5.0$ \\
Over-penetration & \\
& \\
Opposed rows of jets: & 1.25 \\
In-line optimum & 5.0 \\
Staggered optimum & \\
\hline
\end{tabular}


Table 2. Specifications of Configurations

\begin{tabular}{|c|c|c|c|c|c|c|c|c|c|}
\hline Configuration & $\mathrm{S} / \mathrm{H}$ & $\begin{array}{l}\text { Slant } \\
\text { Angle }\end{array}$ & $\mathrm{S}_{1} / \mathrm{H}$ & $\mathrm{S}_{2} / \mathrm{H}$ & L/W & $A_{j} / A_{\infty}$ & Blockage & $\begin{array}{l}\text { Slot } \\
\text { Leading } \\
\text { Edge } \\
(\mathrm{X} / \mathrm{H})\end{array}$ & $\begin{array}{l}\text { Slot } \\
\text { Trailing } \\
\text { Edge } \\
(x / H)\end{array}$ \\
\hline Straight & 0.5 & $0^{\circ}$ & 0.25 & 0.25 & 4 & 0.0189 & $9.7 \%$ & -0.10 & 0.10 \\
\hline Straight & 0.75 & & 0.375 & 0.375 & & & $7.9 \%$ & -0.12 & 0.12 \\
\hline Straight & 1.0 & $\downarrow$ & 0.5 & 0.5 & & & $6.9 \%$ & -0.14 & 0.14 \\
\hline Parallel Slanted & 0.5 & $45^{\circ}$ & 0.25 & 0.25 & & & $34.3 \%$ & -0.06 & 0.06 \\
\hline Parallel Slanted & 0.75 & & 0.375 & 0.375 & & & $28.0 \%$ & -0.08 & 0.08 \\
\hline Parallel Slanted & 1.0 & & 0.5 & 0.5 & & & $24.3 \%$ & -0.09 & 0.09 \\
\hline Perpendicular Slanted & 0.5 & & 0.25 & 0.25 & & & $34.3 \%$ & -0.06 & 0.06 \\
\hline Perpendicular Slanted & 0.75 & & 0.375 & 0.375 & & & $28.0 \%$ & -0.08 & 0.08 \\
\hline Perpendicular Slanted & 1.0 & & 0.5 & 0.5 & & & $24.3 \%$ & -0.09 & 0.09 \\
\hline Perpendicular Slanted & 1.0 & $\downarrow$ & 0.60 & 0.40 & $\downarrow$ & $\downarrow$ & $24.3 \%$ & -0.09 & 0.09 \\
\hline
\end{tabular}

where

$\mathrm{S}=$ Slot Spacing $=\mathrm{S}_{1}+\mathrm{S}_{2}$

$\mathrm{H}=$ Duct Height

$\mathrm{S}_{1}=$ Slot Spacing Parameter (see Figure 6)

$\mathrm{S}_{2}=$ Slot Spacing Parameter (see Figure 6)

$\mathrm{L}=$ Slot Length (Long Dimension)

$\mathrm{W}=$ Slot Width (Short Dimension)

$A_{j}=$ Jet Flow Area

$A_{\infty}=$ Mainstream Flow Area 


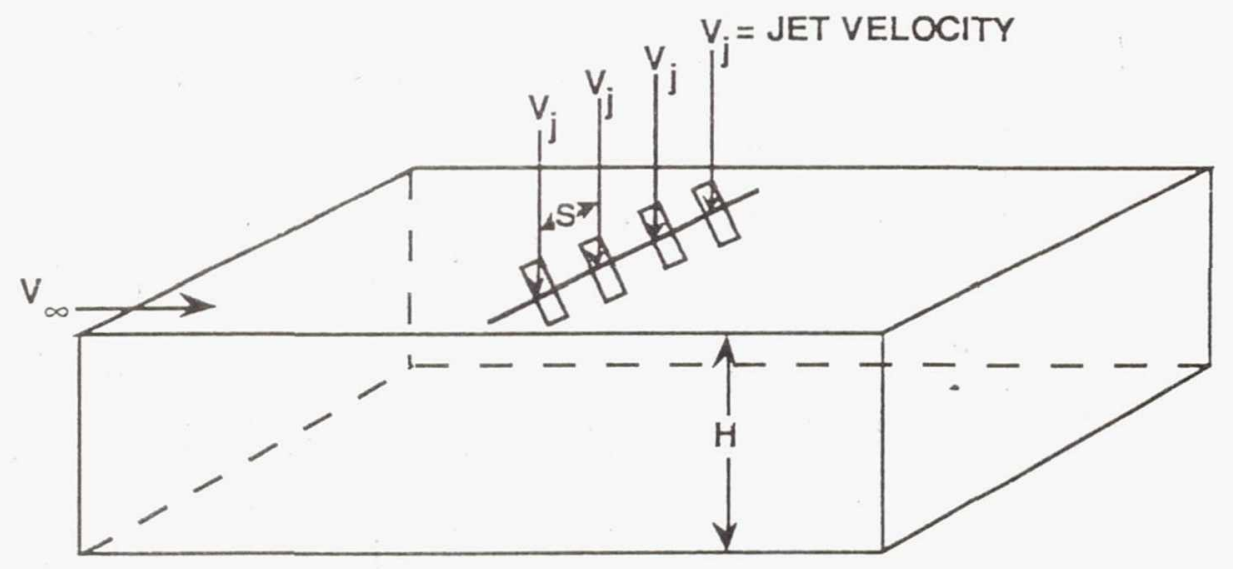

$S \quad=$ Hole Spacing

$\mathrm{D}=$ Equivalent Hole Diameter

$H=$ Test Section Height

$V_{i}=$ Jet Velocity $(\mathrm{m} / \mathrm{s})$

$\mathrm{T}_{j}=$ Jet Tempeature $\left({ }^{\circ} \mathrm{K}\right)$

$V_{\infty}=$ Mainstream Velocity $(\mathrm{m} / \mathrm{s})$

$T_{\infty}=$ Mainstream Tempeature $\left({ }^{\circ} \mathrm{K}\right)$

$J=$ Jet-to-Mainstream Momentum Flux Ratio $\left[\left(\rho_{j} V_{j}^{2}\right) /\left(\rho_{\infty} V_{\infty}^{2}\right)\right]$

MFR $=$ Mass Flow Ratio $\left(\sum \dot{m}_{j} / \dot{m}_{\infty}\right)$

\begin{tabular}{|l|c|c|c|c|c|c|c|c|c|c|}
\hline $\begin{array}{l}\text { ORIFICE } \\
\text { CONFIGURATION }\end{array}$ & $\begin{array}{l}\text { EQUIVALENT } \\
\text { DIA (CM) }\end{array}$ & $\mathrm{S} / \mathrm{H}$ & $\mathrm{S} / \mathrm{D}$ & $\mathrm{H} / \mathrm{D}$ & $\mathrm{V}_{\mathrm{i}}$ & $\mathrm{T}_{\mathrm{j}}$ & $\mathrm{V}_{\infty}$ & $\mathrm{T}_{\infty}$ & $\mathrm{J}$ & MFR \\
\hline $\begin{array}{l}\text { Single Row } \\
45^{\circ} \text { Slots }\end{array}$ & 2.54 & 0.5 & 2.0 & 4.0 & 60.5 & 314.5 & 17.2 & 675.5 & 27.1 & 0.50 \\
\hline
\end{tabular}

Figure 1. Validation Case from Reference 12 


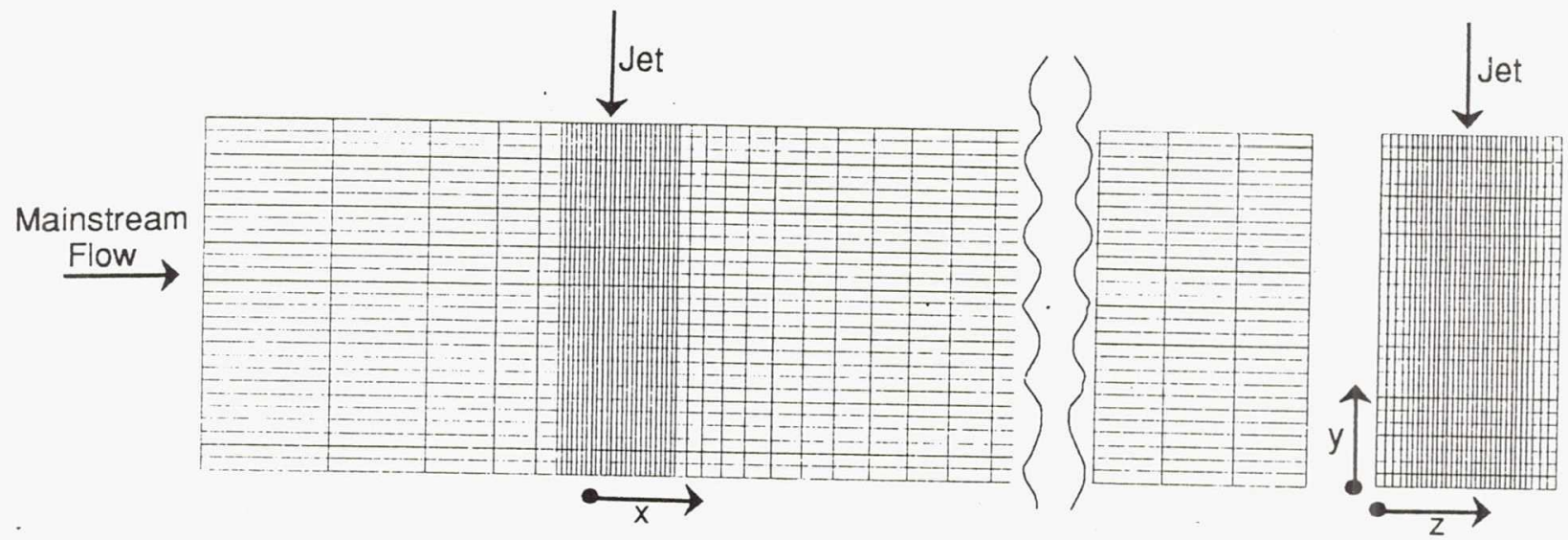

$$
\begin{aligned}
\text { Grid } i=53 \\
j=28 \\
k=32
\end{aligned}
$$
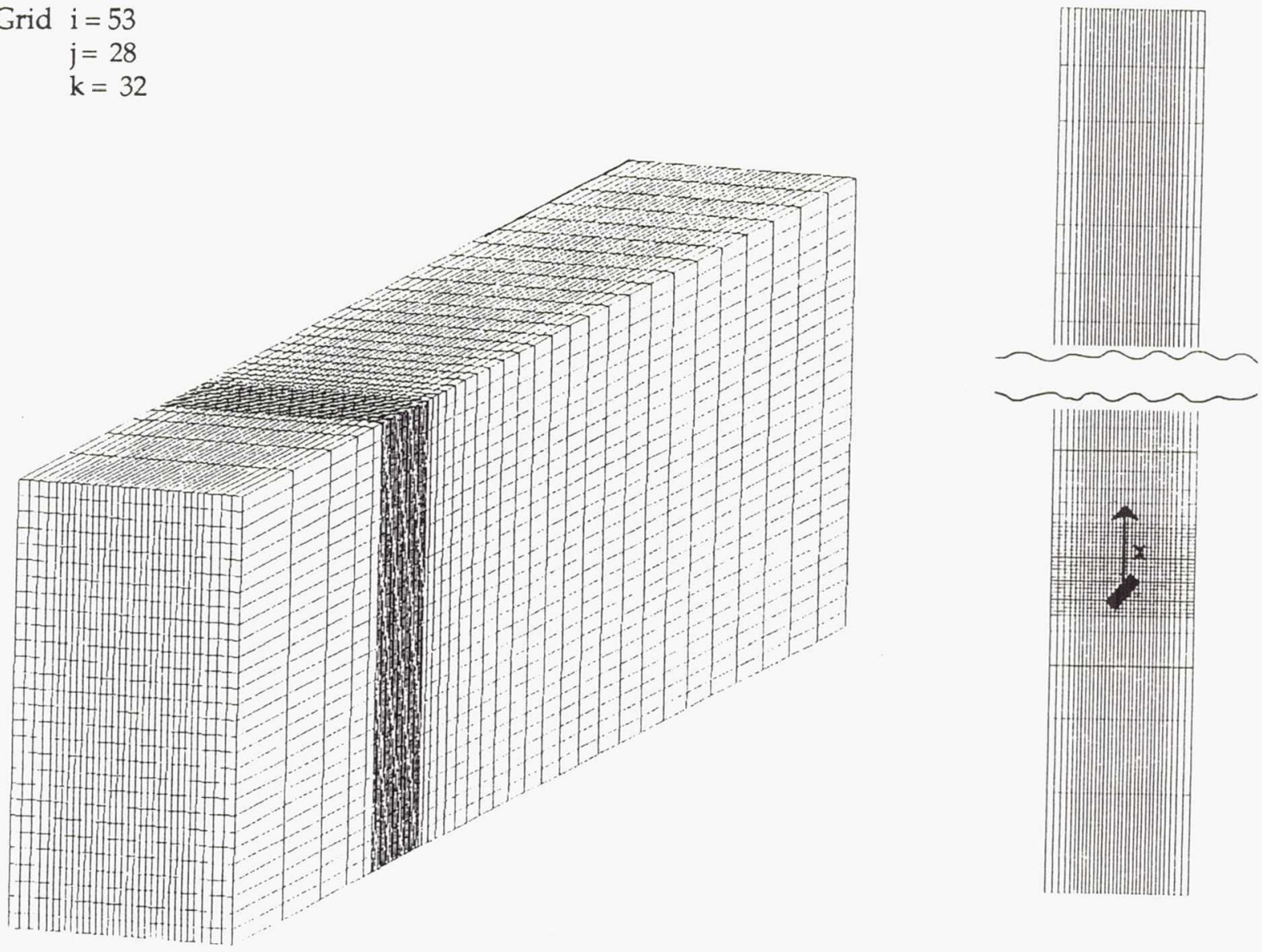

Figure 2. Grid used for Code Validation 

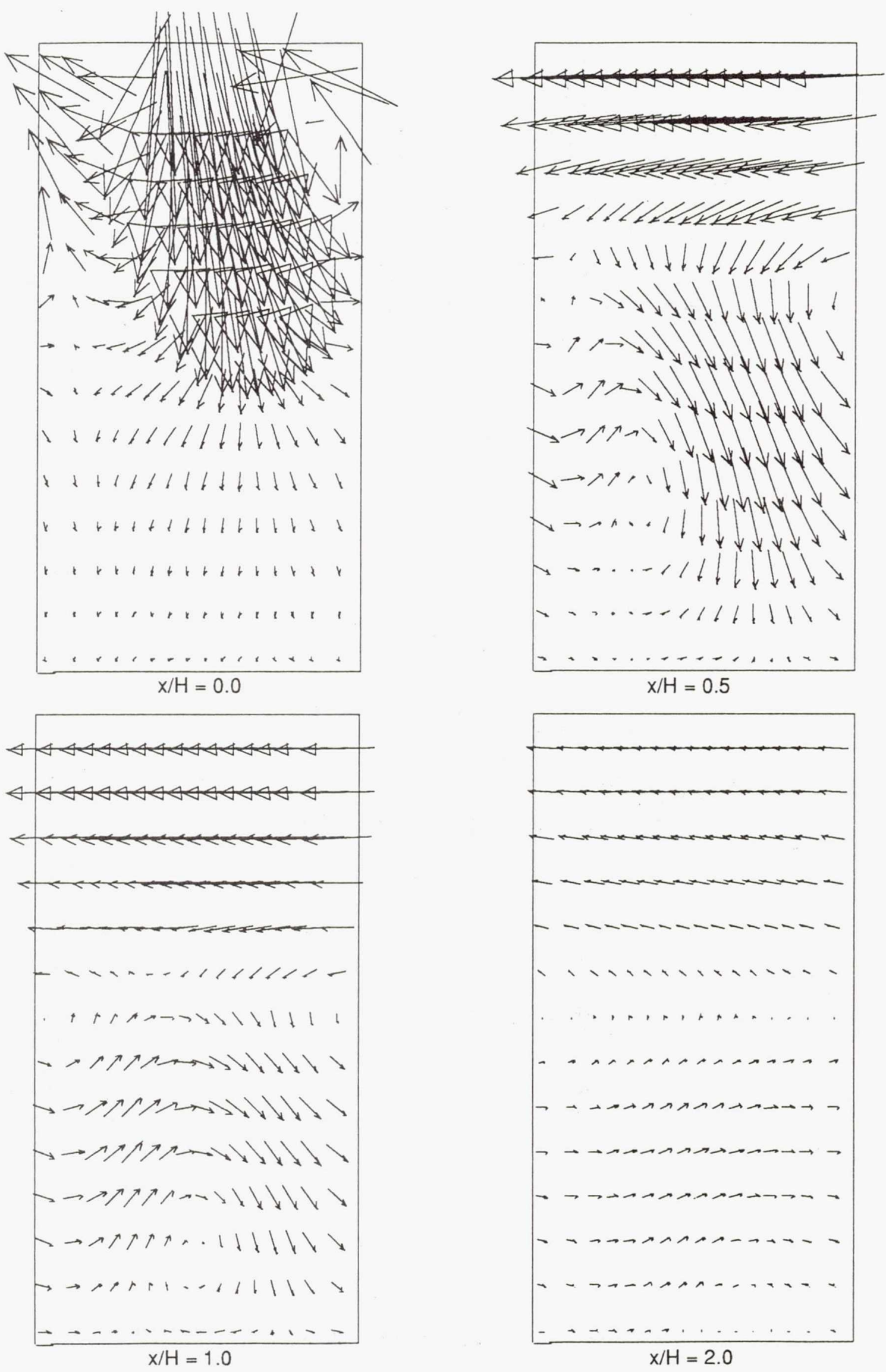

Figure 3. Validation Case: Velocity Vectors 

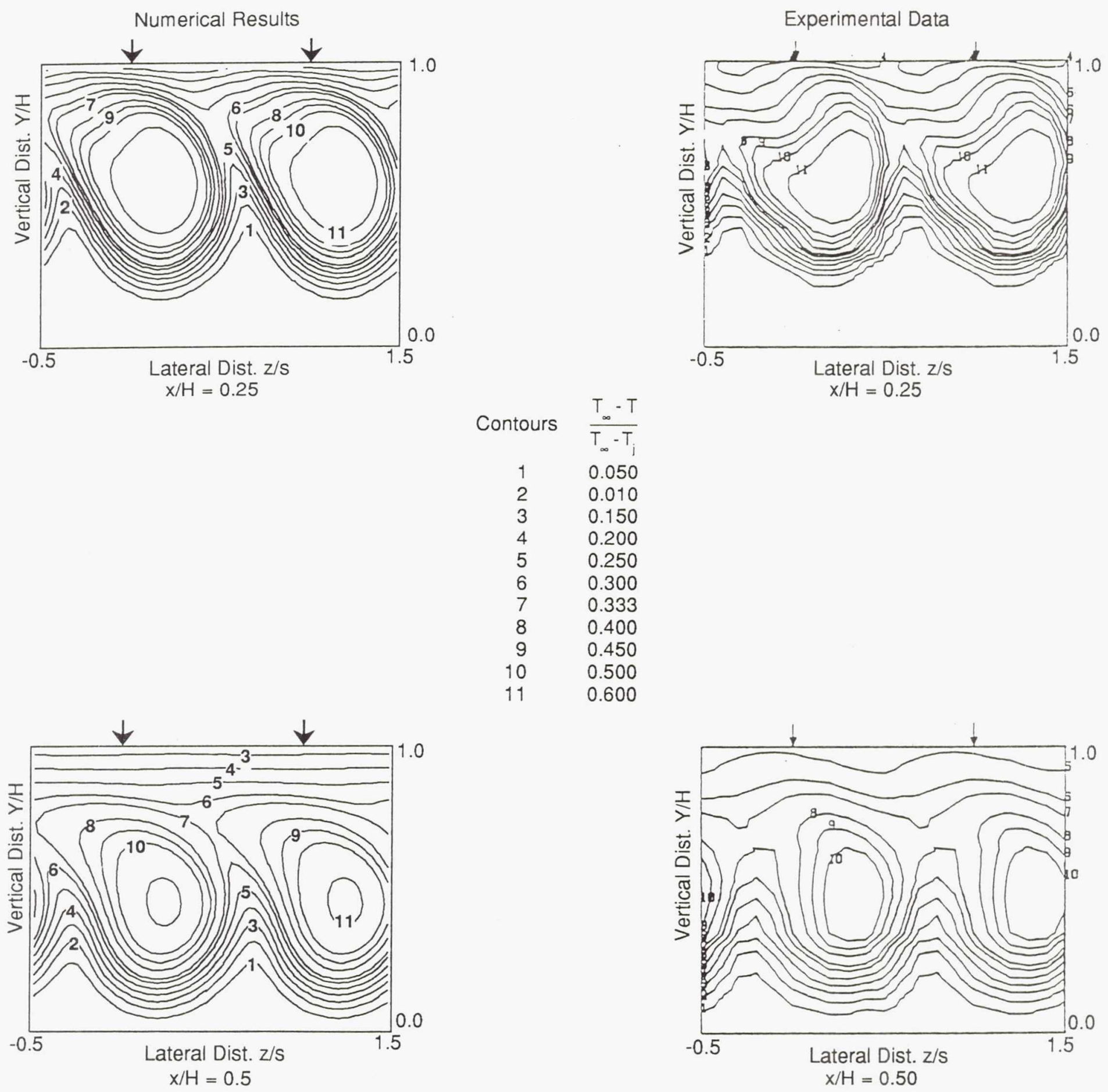

Figure 4. Comparison of Temperature Isotherms between Experimental Results and REFLEQS Calculations 


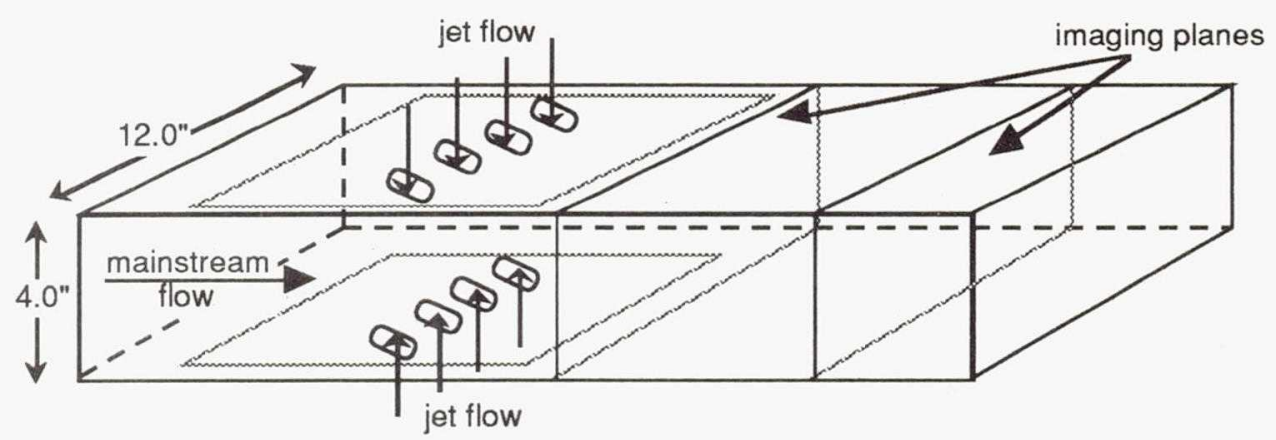

Figure 5. Schematic of Numerical Test Configuration
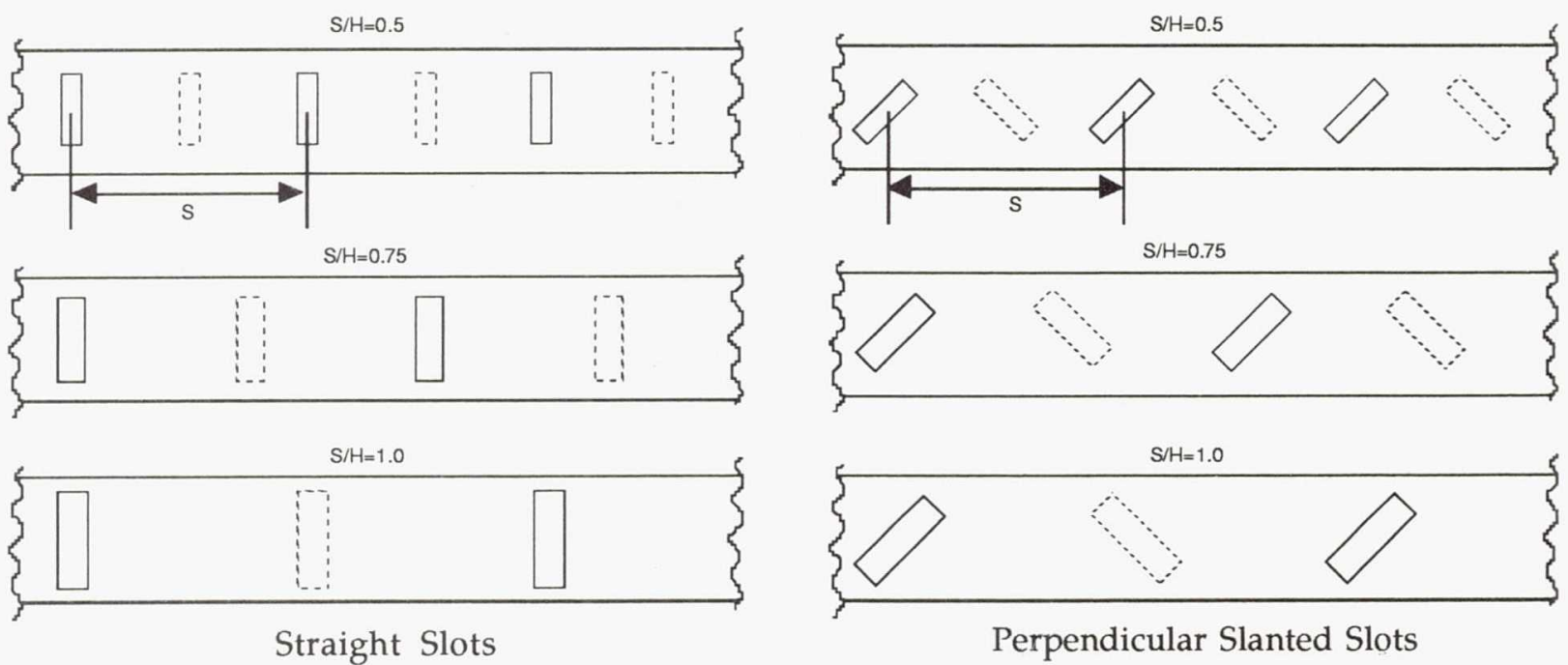

Perpendicular Slanted Slots
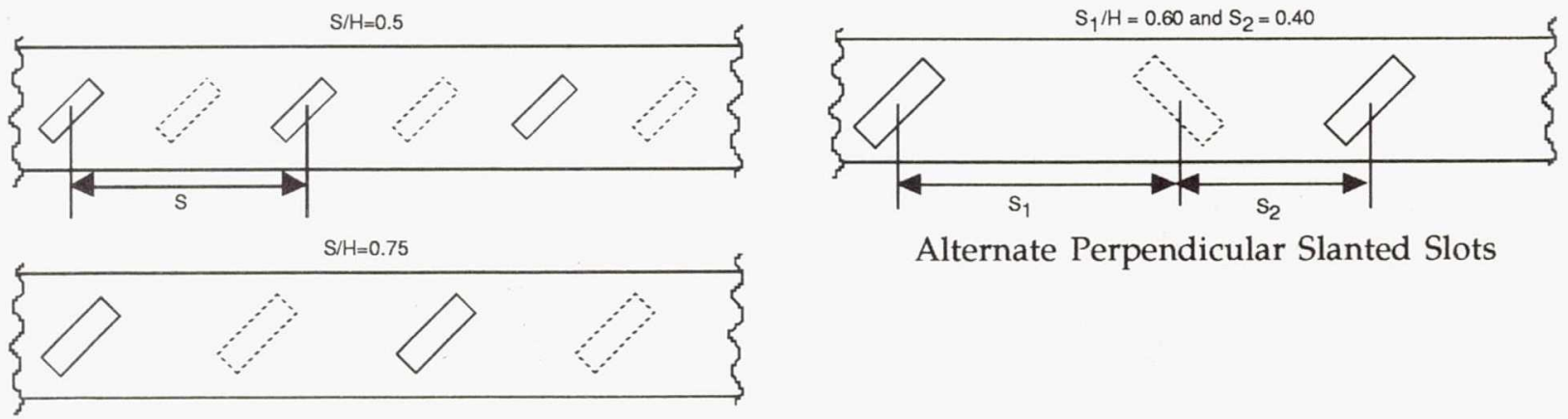

Alternate Perpendicular Slanted Slots

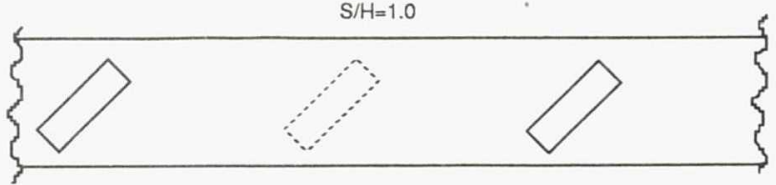

Parallel Slanted Slots

Solid Slot: Top Wall

Dashed Slot: Bottom Wall

Figure 6. Slot Configurations Analyzed 
Page intentionally left blank 


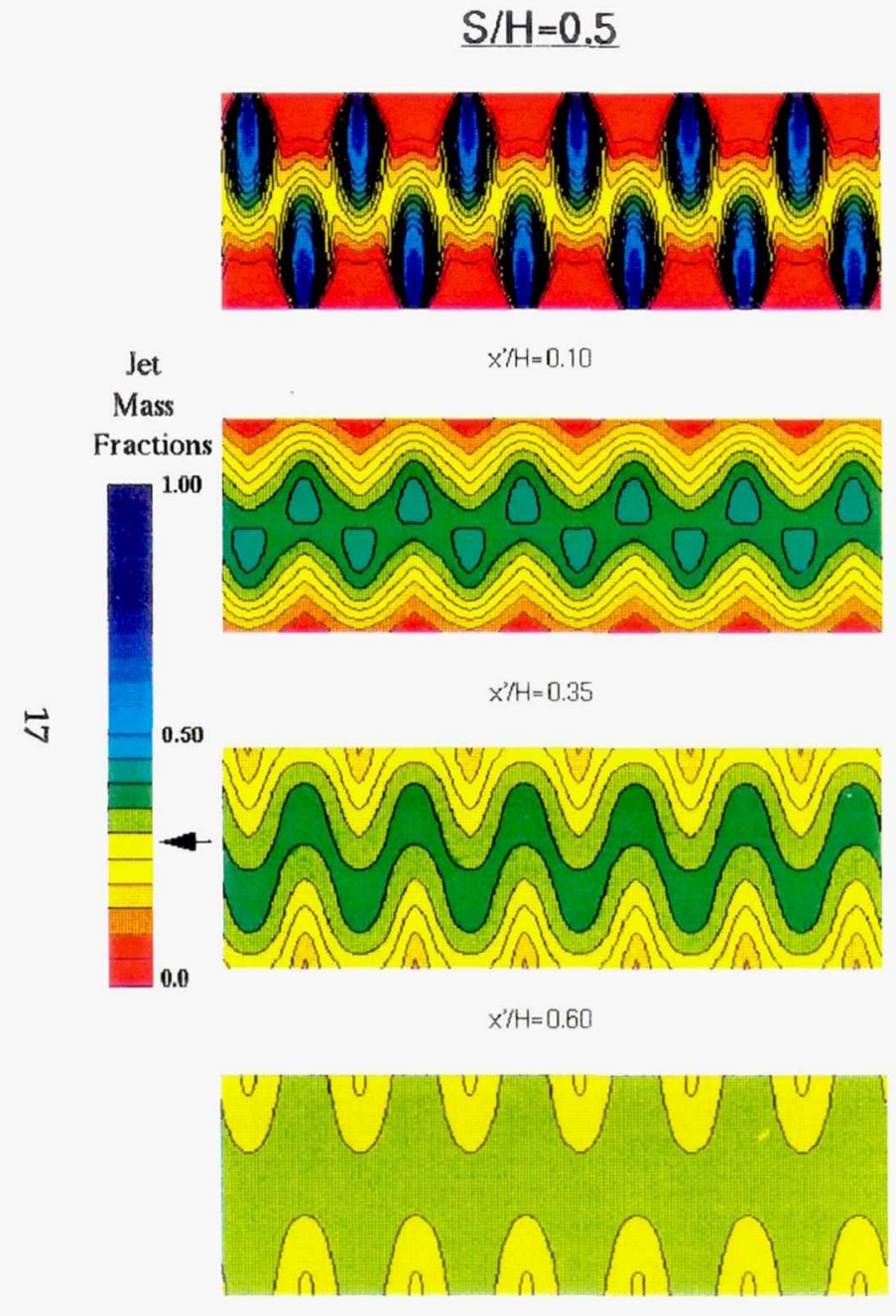

$x^{\prime} / H=1.10$
$\mathrm{S} / \mathrm{H}=0.75$

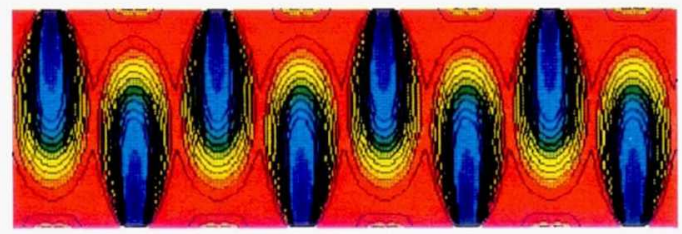

$\boldsymbol{x} / \mathbf{H}=\mathbf{0}\left(x^{\prime} / \mathbf{H}=0.12\right)$

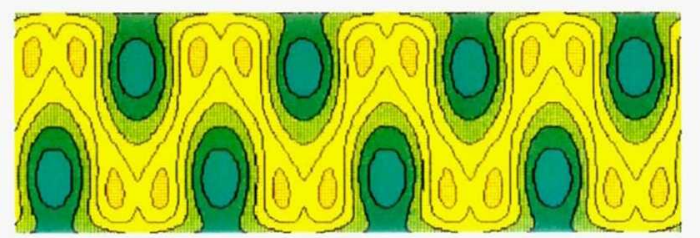

$x / H=0.25\left(x^{\prime} / H=0.37\right)$

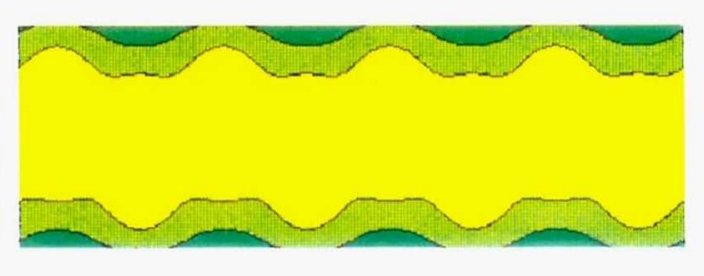

$x / H=0.50\left(x^{\prime} / H=0.62\right)$

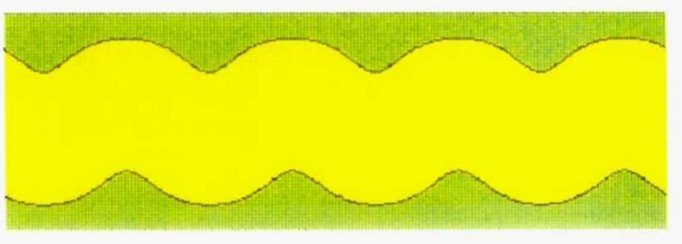

$x / H=1.0\left(x^{\prime \prime} / H=1.12\right)$
$\mathrm{S} / \mathrm{H}=1.0$

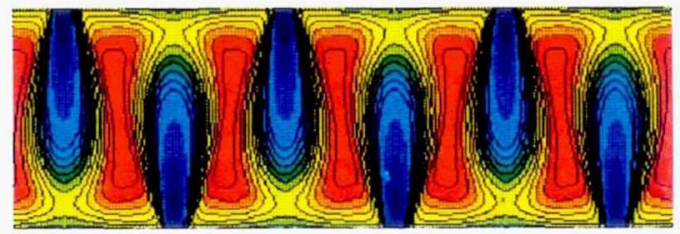

$x^{\prime} / H=0.14$

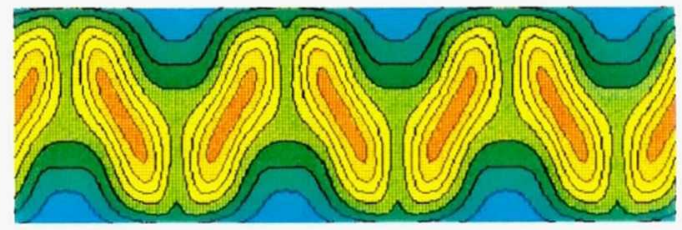

$x^{\prime} / H=0.39$

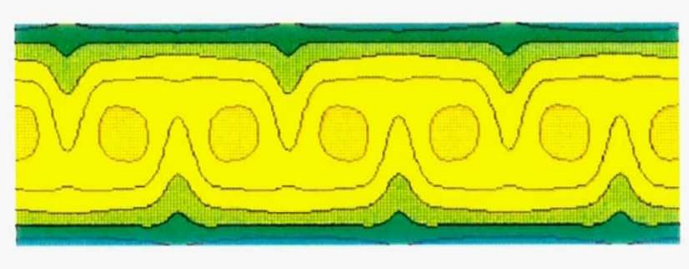

$x^{\prime} / H=0.64$

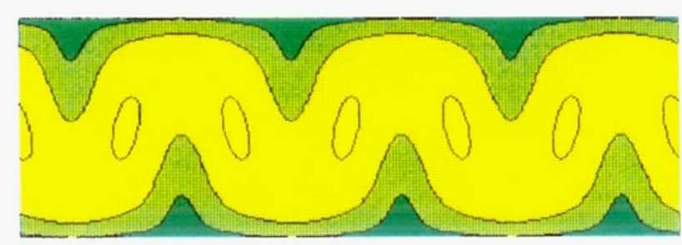

$x^{\prime}: H=1.14$

Figure 8. Jet Mass Fraction Color Maps for Straight Slots: Momentum Flux Ratio of 100, Mass Flow Ratio of 0.383 (Symmetric Boundaries) 
Page intentionally left blank 


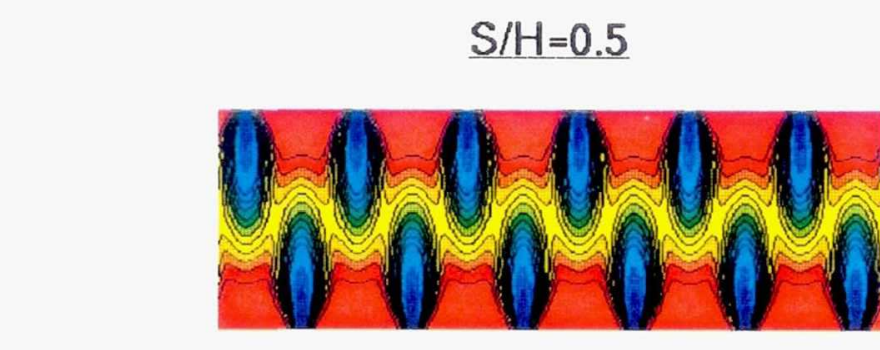

$x^{\prime} / H=0.10$

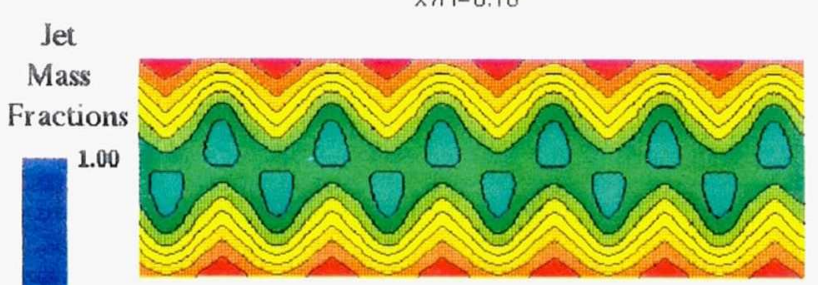

$x^{\prime} / H=0.35$

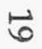
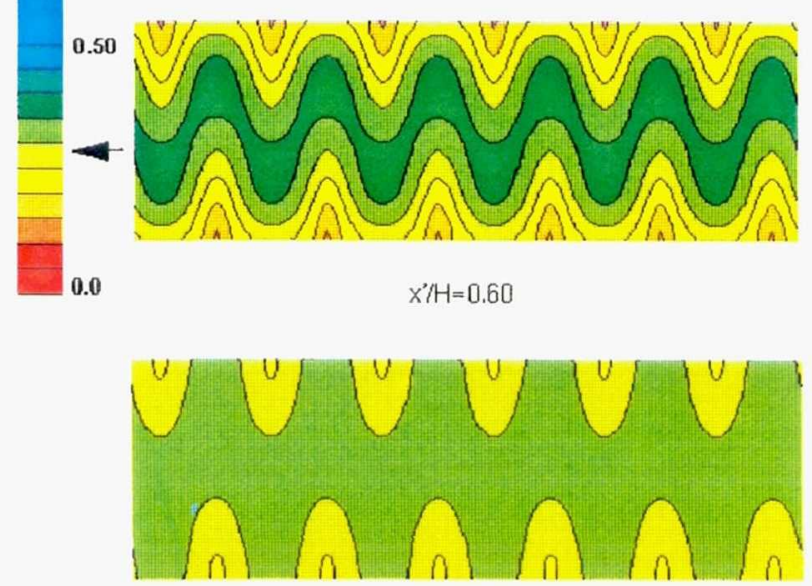

$x^{\prime} / H=1.10$
$\underline{S / H}=0.75$

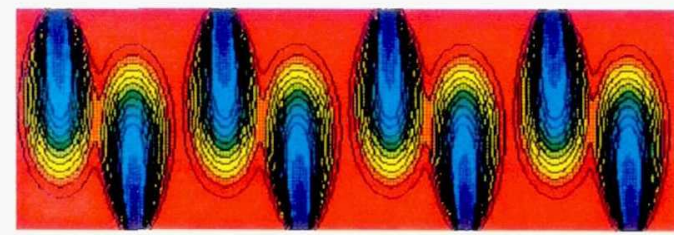

$x / H=0\left(x^{\prime} / H=0.12\right)$

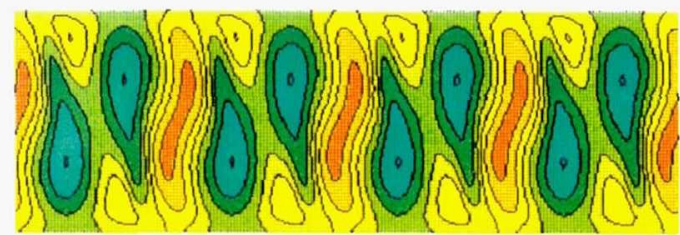

$x / H=0.25\left(x^{\prime} / H=0.37\right)$

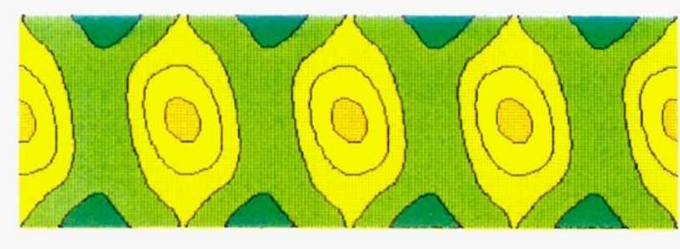

$x / H=0.50\left(x^{*} / H=0.62\right)$

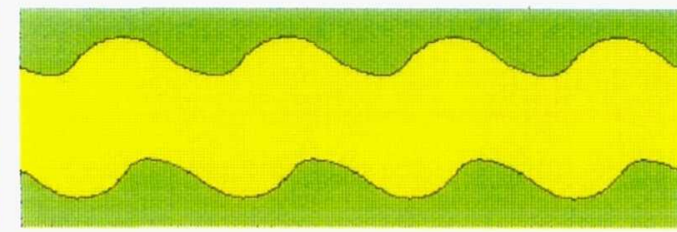

$\boldsymbol{x} / \mathbf{H}=\mathbf{1} . \mathbf{0}\left(x^{\prime} / \mathbf{H}=1.12\right)$
$\underline{S / H}=1.0$

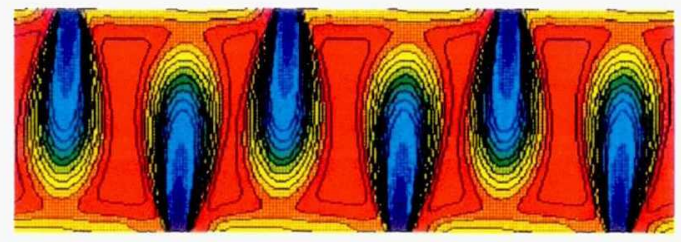

$x^{\prime} / H=0.14$

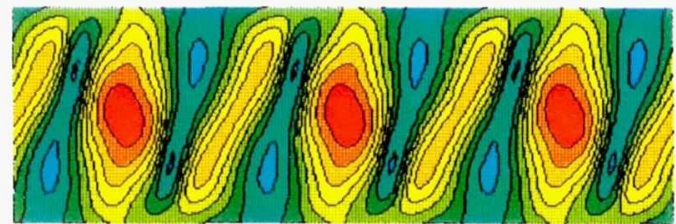

$x^{\prime} / H=0.39$

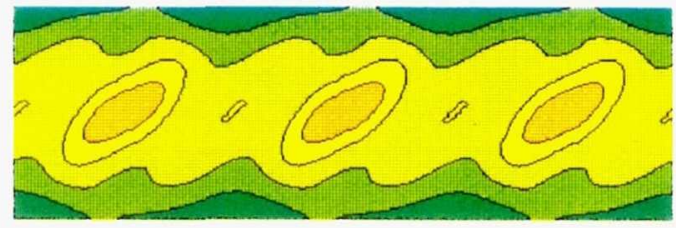

$x^{\prime} / H=0.64$

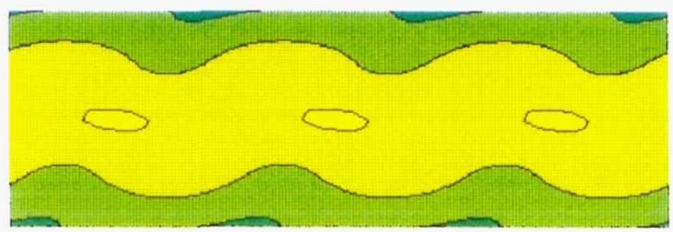

$x^{\prime} / H=1.14$

Figure 9. Jet Mass Fraction Color Maps for Straight Slots: Momentum Flux Ratio of 100, Mass Flow Ratio of 0.383 (Cyclic Boundaries) 
Page intentionally left blank 


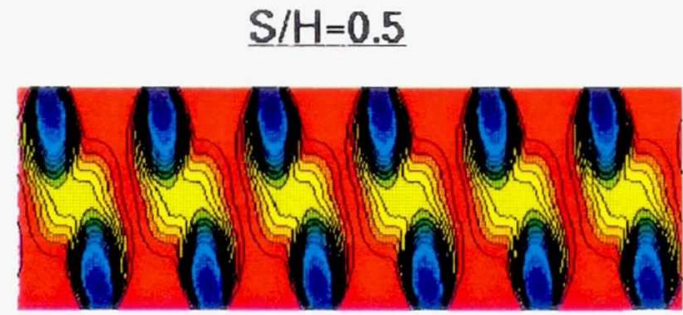

$x^{\prime} / H=0.06$
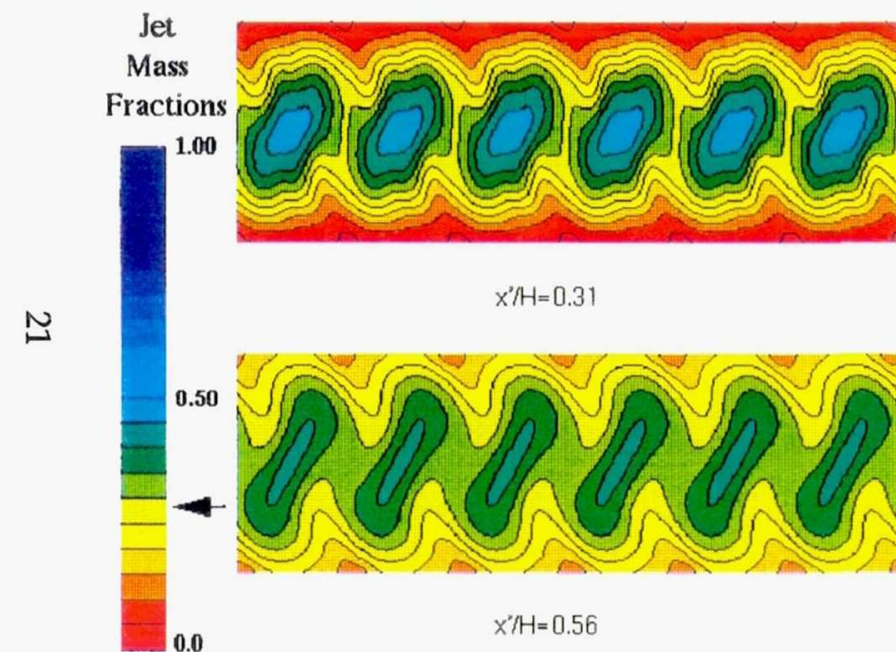

$x^{\prime} / H=0.31$

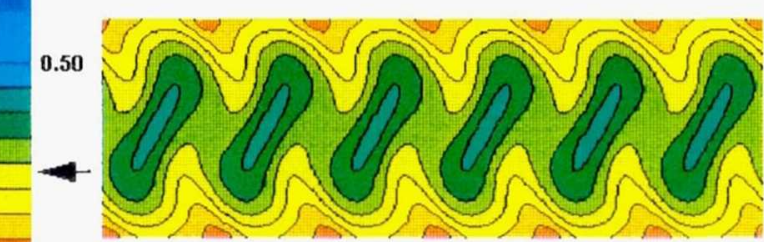

$x^{\prime} / H=0.56$

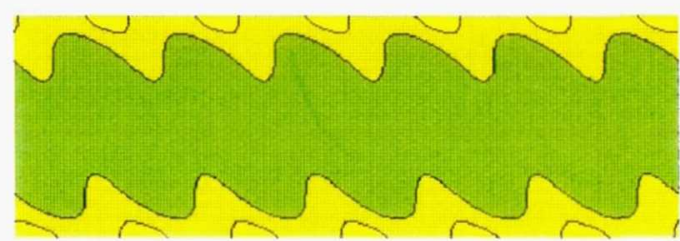

$x^{\prime} / H=1.06$
$S / H=0.75$

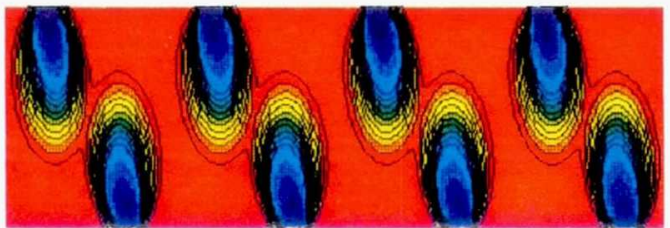

$\boldsymbol{x} / \mathrm{H}=\mathbf{0}\left(\mathrm{x}^{\prime} / \mathrm{H}=0.08\right)$

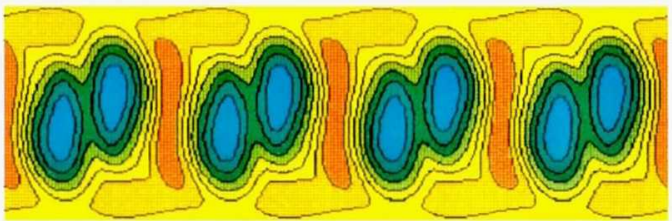

$\boldsymbol{x} / \mathrm{H}=\mathbf{0 . 2 5}\left(\mathrm{x}^{\prime} / \mathrm{H}=0.33\right)$

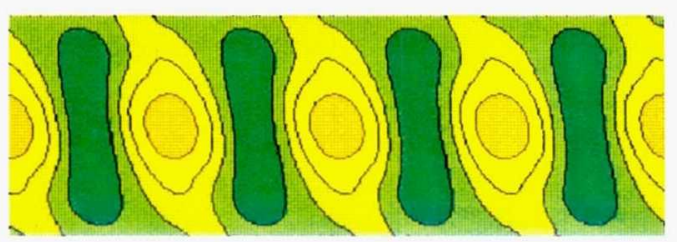

$x / H=0.50\left(x^{\prime} / H=0.58\right)$

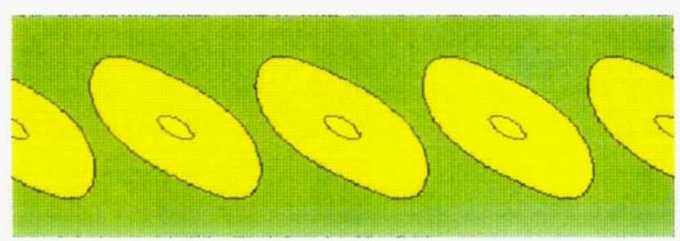

$x / H=1.0\left(x^{\prime} / H=1.08\right)$
$S / H=1.0$

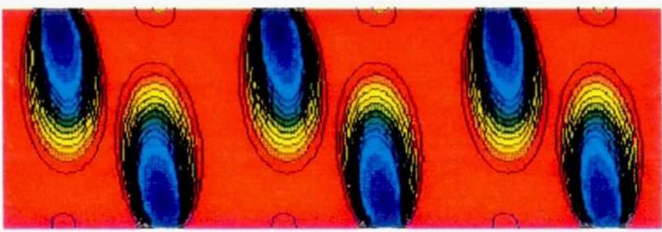

$x^{2} / H=0.09$

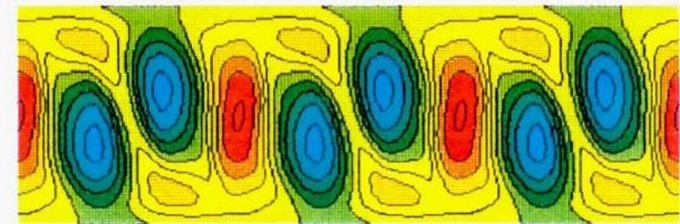

$x^{3} / H=0.34$

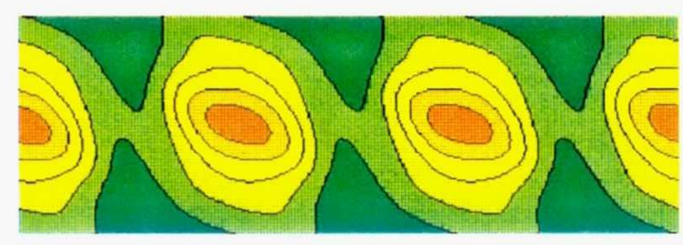

$x^{\prime} / H=0.59$

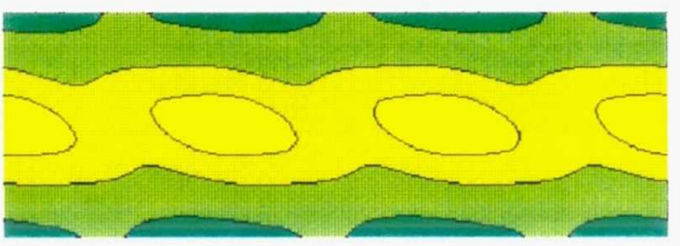

$x^{\prime} / H=1.09$

Figure 10. Jet Mass Fraction Color Maps for Perpendicular Slanted Slots: Momentum Flux Ratio of 100, Mass Flow Ratio of 0.383 (Cyclic Boundaries) 
Page intentionally left blank 


\section{Equally Spaced (S/H1.0)}
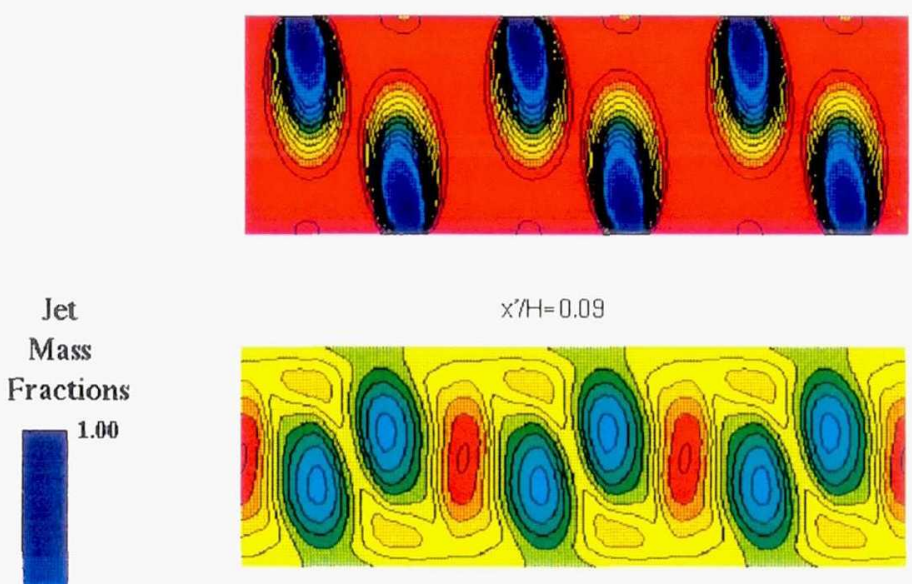

$\tilde{\omega}$

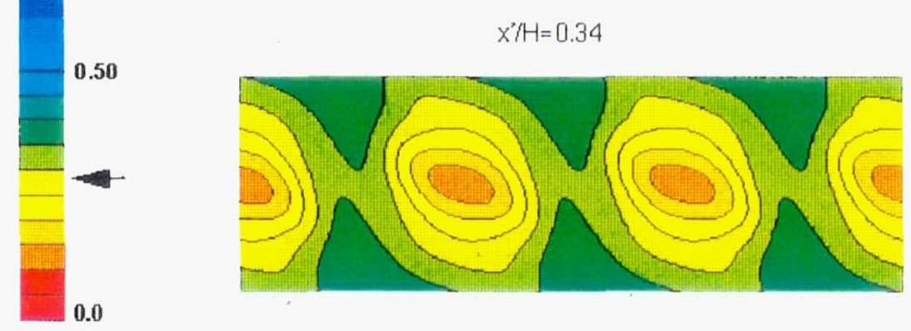

$x^{\prime \prime} / H=0.59$

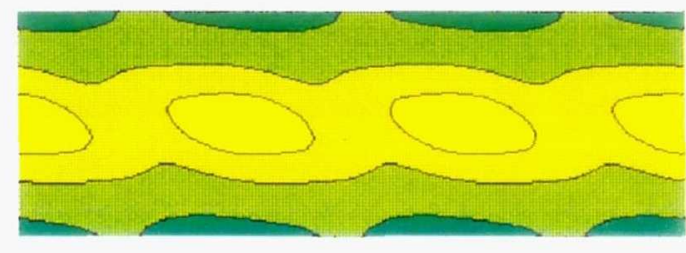

$x^{*} / H=1.09$
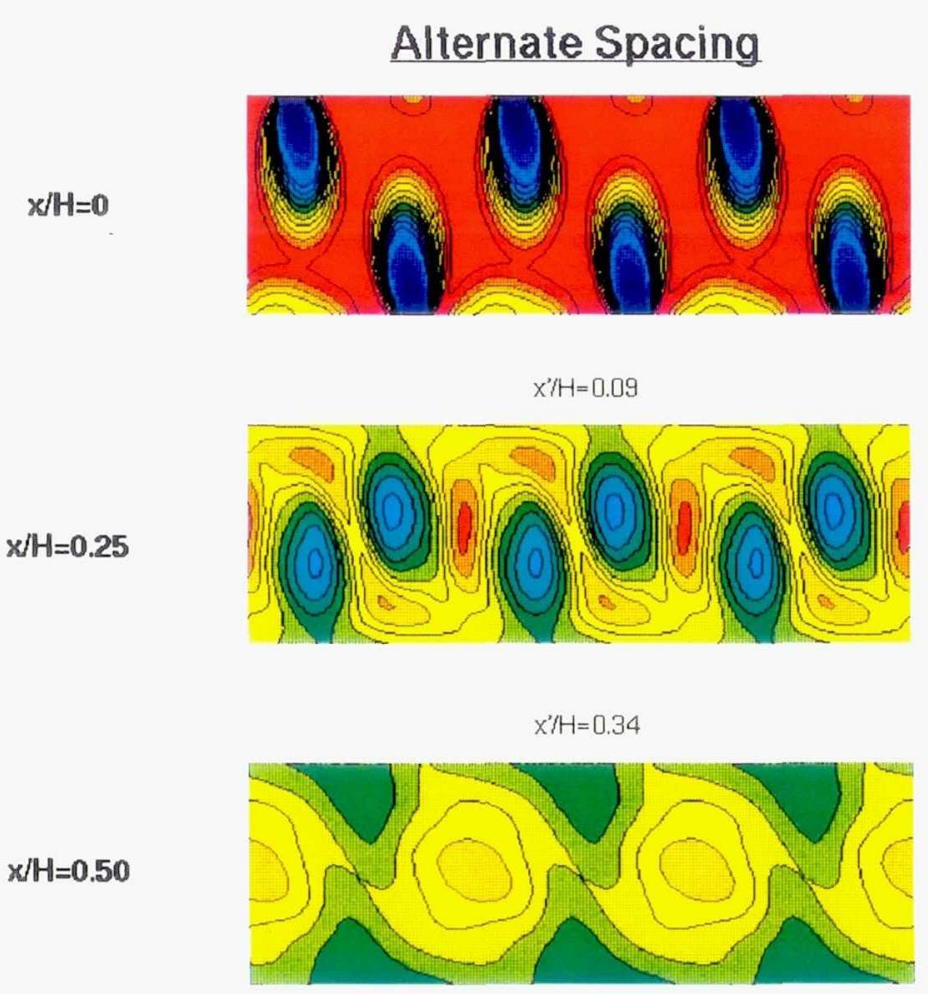

$x^{\prime} / H=0.59$

$x / H=1.0$

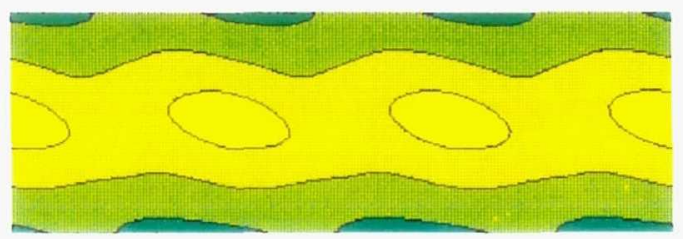

$x^{\prime} / H=1.09$

Figure 11. Jet Mass Fraction Color Maps for Modified Perpendicular Slanted Slots: Momentum Flux Ratio of 100, Mass Flow Ratio of 0.383 (Cyclic Boundaries) 
Page intentionally left blank 


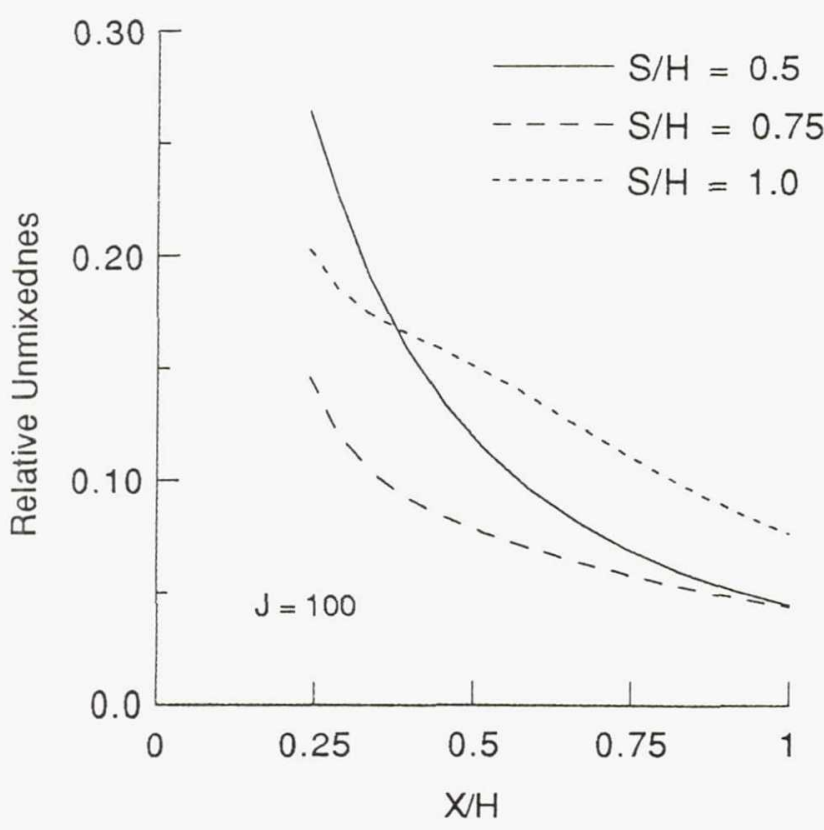

Figure 12. Unmixedness Comparison for Straight Slots (Symmetric Boundaries)

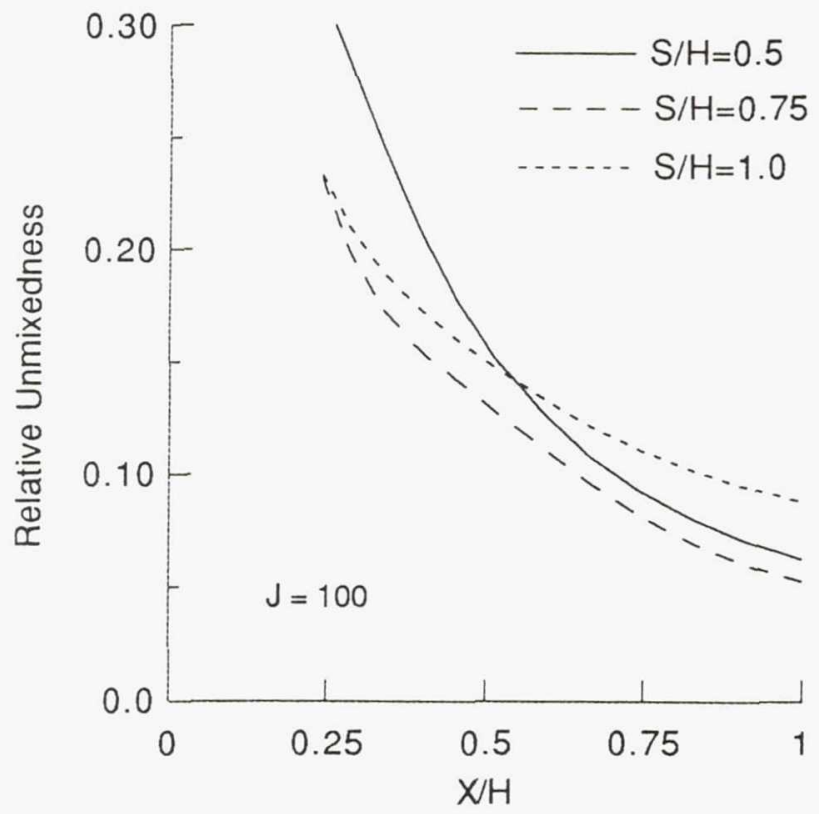

Figure 14. Unmixedness Comparison for Perpendicular Slanted Slots

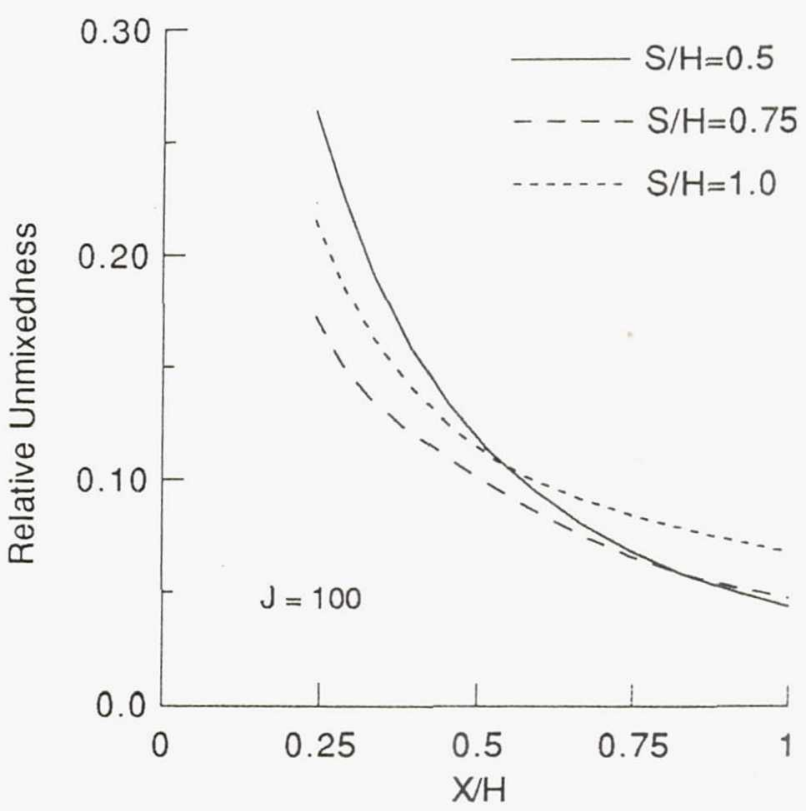

Figure 13. Unmixedness Comparison for Straight Slots (Cyclic Boundaries)

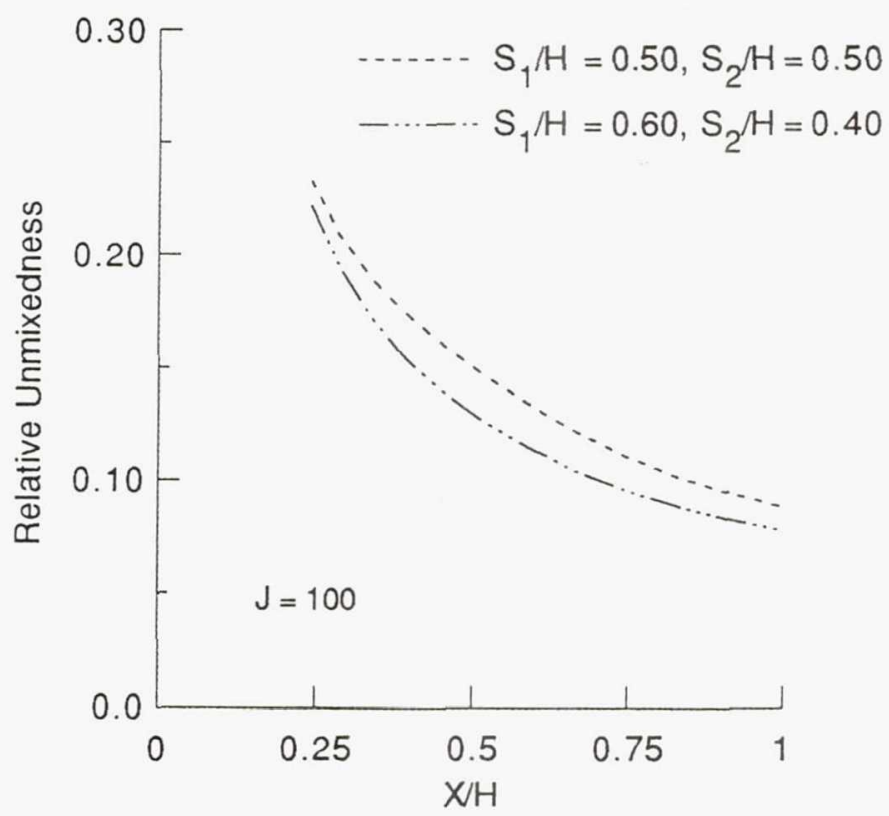

Figure 15. Unmixedness Comparison for

Perpendicular Slanted Slots with Different Slot Spacings $(\mathrm{S} / \mathrm{H}=1)$ 
Page intentionally left blank 
$\underline{S} / \mathrm{H}=0.5$

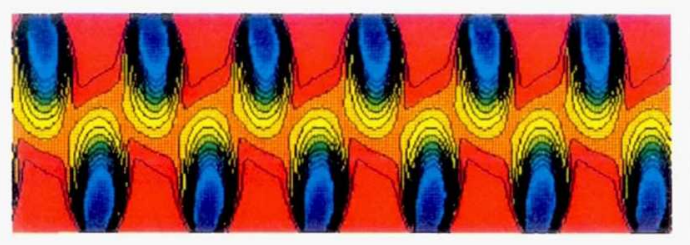

$x^{\prime} / H=0.06$

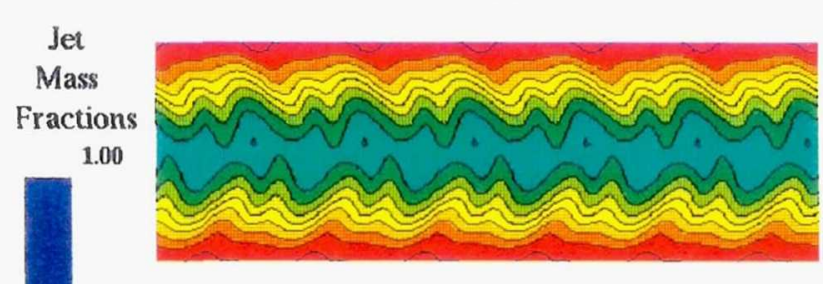

$x^{\prime \prime} / H=0.31$

N

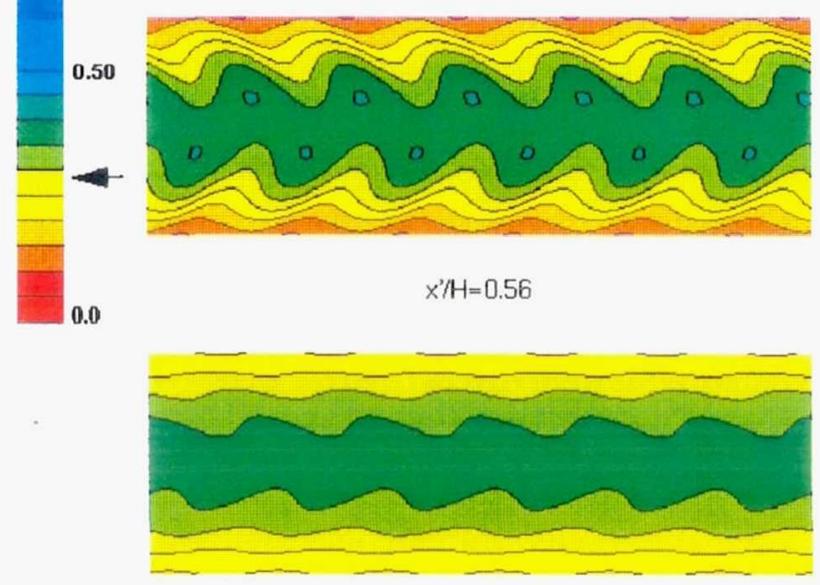

$x^{\prime} / H=1.06$
$\underline{S / H}=0.75$

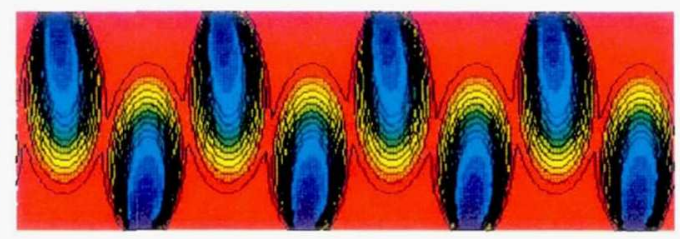

$x^{\prime} / H=0\left(x^{\prime} / H=0.08\right)$

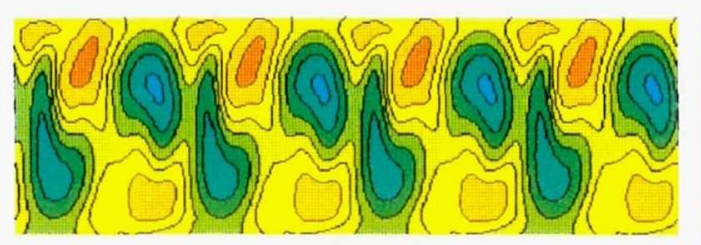

$x / H=0.25\left(x^{3} / H=0.33\right)$

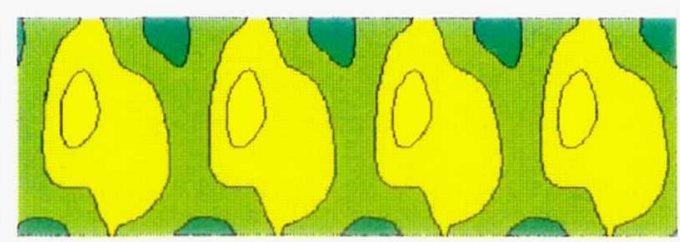

$x / H=0.50\left(x^{3} / H=0.58\right)$

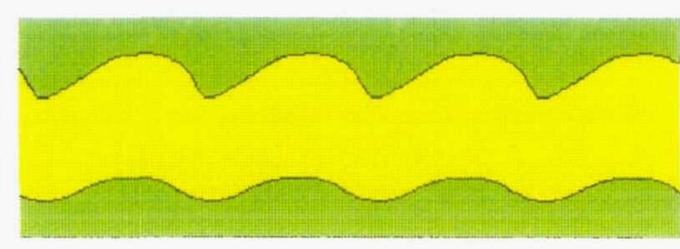

$\mathrm{x} / \mathrm{H}=\mathbf{1 . 0}\left(\mathrm{x}^{\prime} / \mathrm{H}=\mathbf{1 . 0 8}\right)$
$\mathrm{S} / \mathrm{H}=1.0$

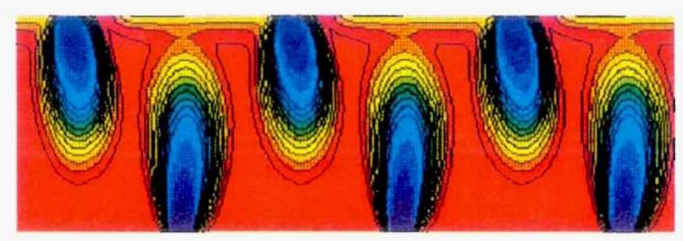

$x^{\prime} / H=0.09$

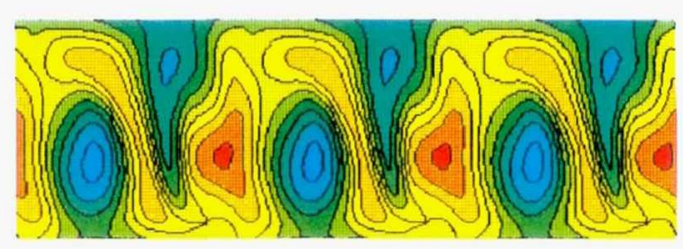

$\mathrm{X}^{\prime} \mathrm{H}=0.34$

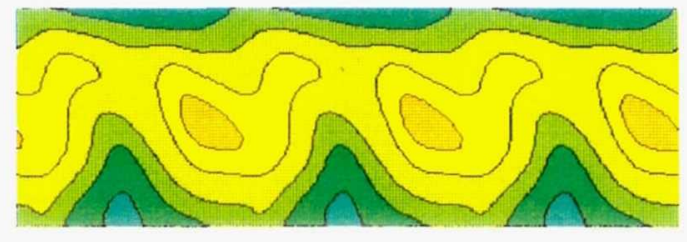

$x^{\prime} / H=0.59$

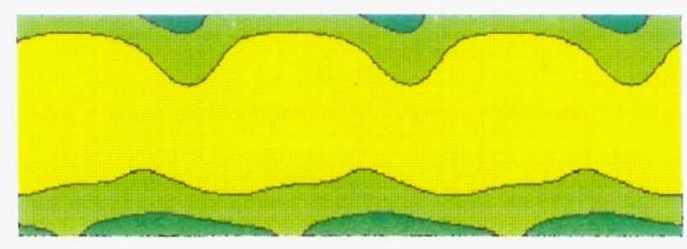

$x^{\prime}: H=1.09$

Figure 16. Jet Mass Fraction Color Maps for Parallel Slanted Slots: Momentum Flux Ratio of 100, Mass Flow Ratio of 0.383 (Cyclic Boundaries) 
Page intentionally left blank 


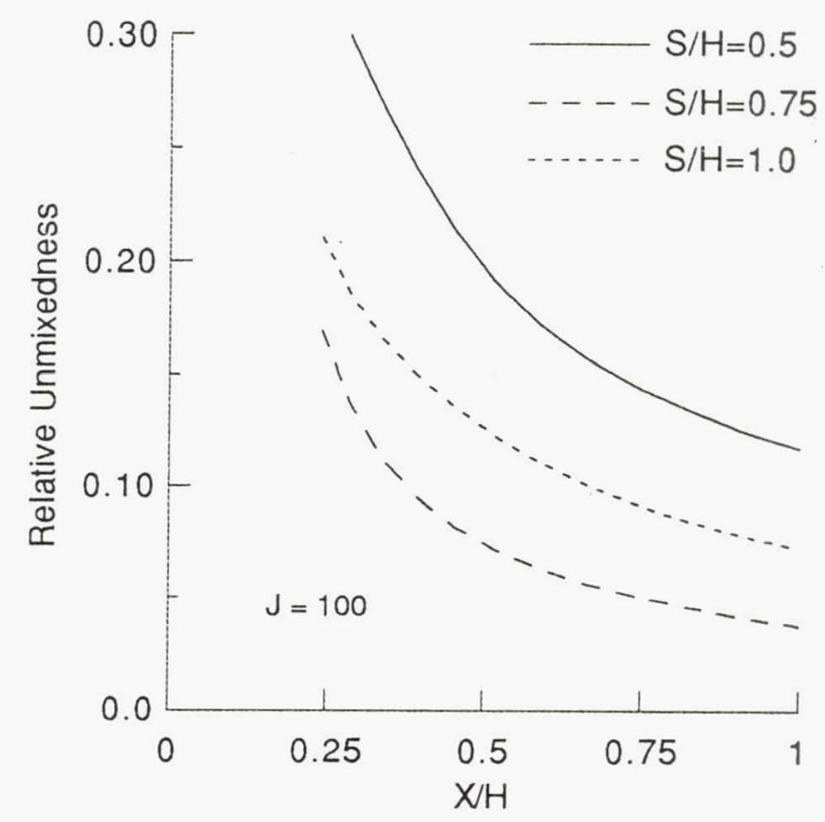

Figure 17. Unmixedness Comparison for Parallel Slanted Slots

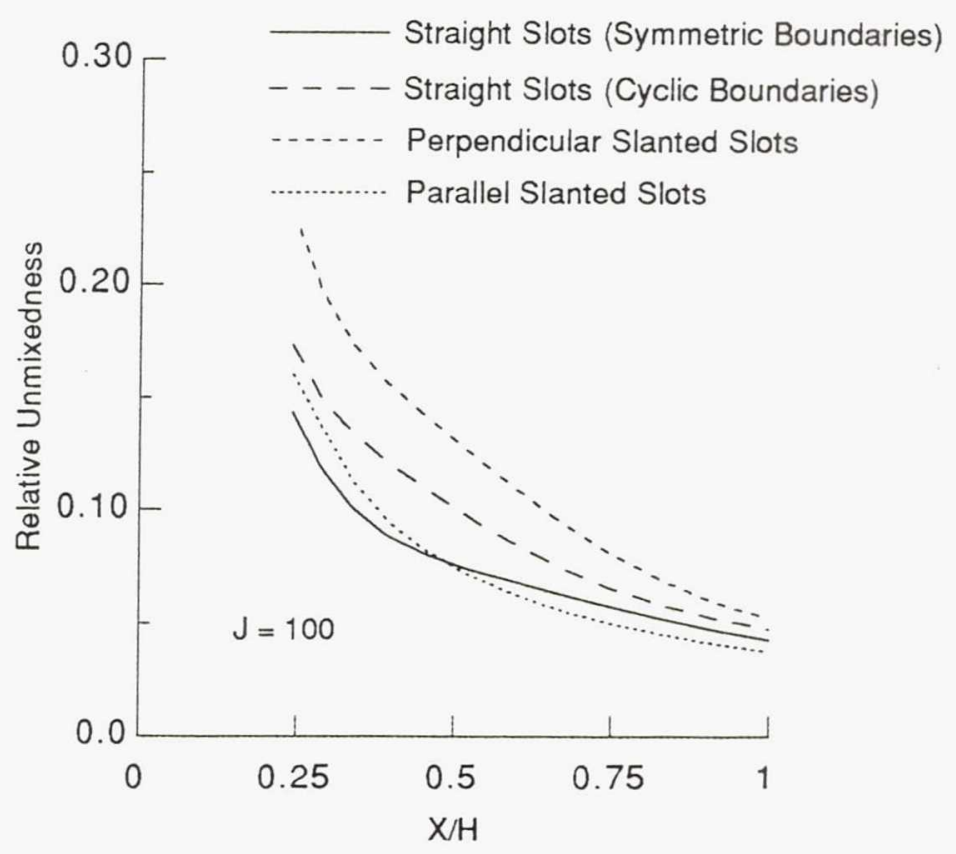

Figure 18. Unmixedness Comparison for the Different Slot Configurations ( $\mathrm{S} / \mathrm{H}$ of 0.75) 


\section{REPORT DOCUMENTATION PAGE}

Public reporting burden for this collection of information is estimated to average 1 hour per response, including the time for reviewing instructions, searching existing data sources, gathering and maintaining the data needed, and completing and reviewing the collection of information. Send comments regarding this burden estimate or any other aspect of this collection of information, including suggestions for reducing this burden, to Washington Headquarters Services, Directorate for information Operations and Reports, 1215 Jefferson Davis Highway, Suite 1204, Arlington, VA 22202-4302, and to the Office of Management and Budget, Paperwork Reduction Project (0704-0188), Washington, DC 20503.

\begin{tabular}{|l|l|r|}
\hline 1. AGENCY USE ONLY (Leave blank) & $\begin{array}{c}\text { 2. REPORT DATE } \\
\text { July } 1992\end{array}$ & $\begin{array}{r}\text { 3. REPORT TYPE AND DATES COVERED } \\
\text { Technical Memorandum }\end{array}$ \\
\hline
\end{tabular}

\section{TITLE AND SUBTITLE}

CFD Mixing Analysis of Jets Injected From Straight and Slanted Slots Into

Confined Crossflow in Rectangular Ducts

6. $\operatorname{AUTHOR}(\mathrm{S})$

D.B. Bain, C.E. Smith, and J.D. Holdeman

\section{FUNDING NUMBERS}

WU-537-02-20

\section{PERFORMING ORGANIZATION NAME(S) AND ADDRESS(ES)}

National Aeronautics and Space Administration

Lewis Research Center

Cleveland, Ohio 44135-3191

E-7087

9. SPONSORING/MONITORING AGENCY NAMES(S) AND ADDRESS(ES)

10. SPONSORING/MONITORING AGENCY REPORT NUMBER

National Aeronautics and Space Administration

Washington, D.C. 20546-0001

NASA TM-105699

AIAA-92-3087

\section{SUPPLEMENTARY NOTES}

Prepared for the 28th Joint Propulsion Conference and Exhibit cosponsored by the AIAA, SAE, ASME, and ASEE, Nashville, Tennessee, July 6-8, 1992. D.B. Bain and C.E. Smith, CFD Research Corporation, 3325-D Triana Blvd., Huntsville, Alabama, 35805 , and J.D. Holdeman, NASA Lewis Research Center, Cleveland, Ohio, 44135. Responsible person, J.D. Holdeman, (216) 433-5846.

\begin{tabular}{|l|l} 
12a. DISTRIBUTION/AVAILABILITY STATEMENT & 12b. DISTRIBUTION CODE
\end{tabular}

Unclassified - Unlimited

Subject Category 07

13. ABSTRACT (Maximum 200 words)

A CFD study was performed to analyze the mixing potential of opposed rows of staggered jets injected into confined crossflow in a rectangular duct. Three jet configurations were numerically tested: 1) straight $\left(0^{\circ}\right)$ slots, 2$)$ perpendicular slanted $\left(45^{\circ}\right)$ slots angled in opposite directions on top and bottom walls, and 3) parallel slanted $\left(45^{\circ}\right)$ slots angled in the same direction on top and bottom walls. All three configurations were tested at slot spacing-to-duct height ratios $(\mathrm{S} / \mathrm{H})$ of $0.5,0.75$, and 1.0; a jet-to-mainstream momentum flux ratio $(\mathrm{J})$ of 100 ; and a jet-to-mainstream mass flow ratio of 0.383 . Each configuration had its best mixing performance at $\mathrm{S} / \mathrm{H}$ of 0.75 . Asymmetric flow patterns were expected and predicted for all slanted slot configurations. The parallel slanted slot configuration was the best overall configuration at $\mathrm{x} / \mathrm{H}$ of 1.0 for $\mathrm{S} / \mathrm{H}$ of 0.75 .

14. SUBJECT TERMS

Dilution; Jet mixing flow; Gas turbine; Combustion chamber; Emissions

15. NUMBER OF PAGES

30

16. PRICE CODE

$\mathrm{A} 03$

\begin{tabular}{l|c|}
\hline $\begin{array}{c}\text { 17. SECURITY CLASSIFICATION } \\
\text { OF REPORT } \\
\text { Unclassified }\end{array}$ & $\begin{array}{c}\text { 18. SECURITY CLASSIFICATION } \\
\text { OF THIS PAGE } \\
\text { Unclassified }\end{array}$ \\
\hline
\end{tabular}

19. SECURITY CLASSIFICATION OF ABSTRACT Unclassified

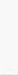

\section{LIMITATION OF ABSTRACT}

